Military Technical College Kobry El-Kobbah, Cairo, Egypt

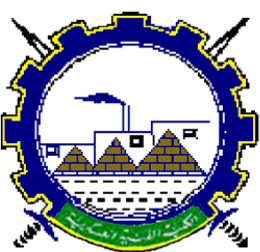

I.C.E.E.2016 $8^{\text {th }}$ International Conferenc

on

Chemical \& Environmenta Engineering 19 - 21 April 2016

PCEA -1

\title{
Electrooxidation of Methanol and Ethanol in Alkaline Solutions on Modified Platinum Electrode
}

\author{
M. M. Hefny ${ }^{*}$, S. Abd El Wanees ${ }^{\dagger}$ and Y. Atef ${ }^{*}$
}

\begin{abstract}
:
This work aims to activate a platinum electrode by repetitive cyclic electrochemical polarization of smooth platinum in alkaline solutions. The resultant modified electrode has been tested as an electro-catalyst for oxidation of candidate fuels, viz. methanol and ethanol. A comparison has been made between the two alcohols with regard to the kinetics of their electro-oxidation. The effect of several kinetic variables has been reported. The results reveal that the modified platinum electrode is a good catalyst for their electro-oxidation in alkaline media. The advantage of this surface is the inhibition of poisoning of Pt by $\mathrm{CO}$ intermediate. Change of charge density with number of cycles reveals the extent of increase of surfaces activation is due to increase of surface roughness. The onset potential for the electrooxidation of ethanol is less than that of methanol on the developed surface. Electro-oxidation in $0.05 \mathrm{M} \mathrm{KOH}$ is more feasible than in $0.1 \mathrm{M} \mathrm{KOH}$ possibly due to the less adsorption of the hydroxyl ion.
\end{abstract}

Keywords: Methanol electrooxidation; Ethanol electrooxidation; modified platinum; Electrocatalysis

* Chemistry Department, Faculty of Science, Cairo University, Giza, Egypt

$\uparrow$ Chemistry Department, Faculty of Science, Zagazig University, Zagazig, Egypt \& Chemistry Department, Faculty of Science, University of Tabuk, Tabuk, Kingdom of Saudi Arabia

+ Chemistry Administration, Cairo, Egypt.

e-mail of correspondence: jasy9@yahoo.com 


\author{
Military Technical College \\ Kobry El-Kobbah, \\ Cairo, Egypt
}

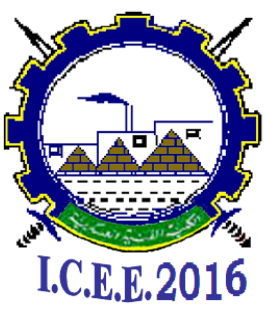

$8^{\text {th }}$ International Conferenc

on

Chemical \& Environmenta Engineering

$19-21$ April 2016

\section{Introduction}

In the last few years, the interest in alkaline fuel cells (AFCs) increased, mainly due to more favorable oxygen reduction and fuel oxidation reactions with a variety of non-noble metal catalysts (e.g., Fe, Co, and Ni). In terms of the catalysts employed in direct alcohol fuel cells (DAFCs), Pt and Pt-based catalysts are commonly used; however, the high price and low tolerance to $\mathrm{CO}$ poisoning limit its wide practical application as anode catalysts of DAFCs. Owning to their many striking feature over other types of fuel cell, such as high energy density, simple construction, low temperature of operation, environmental friendliness, DAFCs using liquid alcohol fuel have attracted considerable attentions in many fields, and they have significant potential to become a leading technology for energy conversion in a variety of applications. Among alcohols methanol, ethanol, propanol and iso-propanol [1], can be used in DAFCs.

The previous studies indicate that the electro-catalytic activity of some metal catalysts is closely related to the $\mathrm{pH}$ value of electrolytic solution [2,3]. For examples, $\mathrm{Pd}[3]$ and $\mathrm{Au}$ [4] have poor catalytic activity in acid media but display quite high activity in alkaline media. This means that under alkaline conditions, the reaction mechanism and kinetics of alcohol oxidation are significantly improved [2,3]. A problem with alkaline fuel cells is the carbonation of the solution due to $\mathrm{CO}_{2}$ production of the fuel oxidation and from air:

$$
2 \mathrm{OH}^{-}+\mathrm{CO}_{2} \rightarrow \mathrm{CO}_{3}{ }^{2-}+\mathrm{H}_{2} \mathrm{O}
$$

This can cause solid precipitation of carbonate salts on the porous electrode and a $\mathrm{pH}$ decrease in the alkaline electrolyte solution [5]. Consequently, it leads to a reduction in reactivity for fuel oxidation in the system [6].

This study demonstrates the feasibility of applying oxygen containing species formed by cyclic polarization on $\mathrm{Pt}$ to activate it for electro-oxidation of methanol and ethanol in alkaline media. The modification of Pt electrode is an excellent support and beneficial for the electro-oxidation process.

\section{Experimental}

Voltammetric measurements were conducted in a $50 \mathrm{ml}$ conventional three compartments cell in $0.05 \mathrm{M}$ and $0.1 \mathrm{M} \mathrm{KOH}$ with temperature controller. As WE pure $\mathrm{Pt}\left(0.4 \mathrm{~cm}^{2}\right.$ sheet, Aldrich, thermocouple quality) was used. A saturated calomel electrode (SCE) connected to the electrochemical cell by a Luggin capillary, was used as the reference. The counter electrode was a piece of thin rod of platinum of area about $0.3 \mathrm{~cm}^{2}$. All potentials, E, given here are referred to SCE. Solutions were made using high purity (Analar grade) chemicals and triply distilled water. Before each experiment, the smooth working electrodes were abraded with a fine grade emery paper followed by washing with triply distilled water. The electrode was coated with hydrated Pt oxide by the repetitive cycling at a sweep rate of $2000 \mathrm{mV} \mathrm{s}^{-1}$ till 


\author{
Military Technical College \\ Kobry El-Kobbah, \\ Cairo, Egypt
}

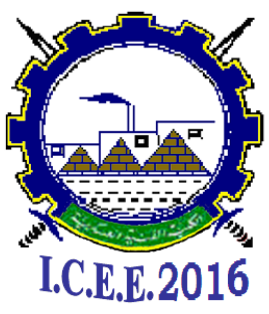

$8^{\text {th }}$ International Conferenc

on

Chemical \& Environmenta Engineering

$19-21$ April 2016

a specified number of cycles $(\mathrm{N})$ in pure $0.05 \mathrm{M}$ or $0.1 \mathrm{M} \mathrm{KOH}$, at $25{ }^{\circ} \mathrm{C}$. The lower and upper potential limits of the cycle are $-400 \mathrm{mV}$ and $+400 \mathrm{mV}$ vs. SCE, respectively. The organic reductant is spectroscopically pure grade supplied from Merck. The electrode potential was controlled by a voltage scan generator, an automatically-controlled electronic Wenking Laboratory Poteniostat (LB 75). DC voltammograms were recorded using Allen, Model 1000 X-Y recorder.

Each experiment was carried out in a freshly prepared solution and with a newly polished electrode surface. After cyclization, the electrolyte was replaced by pure $0.05 \mathrm{M}$ or $0.1 \mathrm{M}$ $\mathrm{KOH}$ free or containing the alcohol. The cyclic voltammograms were recorded for each solution between the previously specified potential limits at a scan rate of $50 \mathrm{mV} \mathrm{s}^{-1}$. The oxidation current density of the reductant, $\mathrm{j}$, was measured as the difference in the anodic current densities for the first cycle in the presence of the reductant and in its absence (pure $0.05 \mathrm{M}$ or $0.1 \mathrm{M} \mathrm{KOH}$ ) at the same potential of -400 to $+400 \mathrm{mV}$. The current densities are referred to the geometric area.

\section{Results and Discussion}

\subsection{Modification process on Pt in KOH}

It is known that the chemical stability of the catalysts over longer periods of time (fuel cell durability studies) is an important issue that still needs to be considered and is suggested for further investigations. It can significantly enhance electrocatalytic activity of $\mathrm{Pt}$ as anode in the alcohol electro-oxidation. In alkaline media and because of the presence of oxide, $\mathrm{OH}_{\mathrm{ads}}$ (adsorbed $\mathrm{OH}$ species) can be formed at lower potentials, which can transform the CO-like poisoning species adsorbed on catalyst surfaces to $\mathrm{CO}_{2}$, releasing the active sites for electrochemical reactions. The kinetics of growth of thin anodic oxide films at platinum electrodes is studied in alkaline solutions of different $\mathrm{pH}$ [7].

\subsubsection{Cyclic Voltammetry of Pt in $0.1 \mathrm{M} \mathrm{KOH}$}

The electrochemical behavior of modified Pt electrode revealed from cyclic voltammograms (CVs) in $0.1 \mathrm{M} \mathrm{KOH}$ is shown in Fig. (1), the cyclization time (t) increases from 0 to 15 minutes. The anodic peak $\left(\mathrm{I}_{\mathrm{a}}\right)$ found in the range -6 to $-250 \mathrm{mV}$ corresponds to the $\mathrm{O}-$ electrosorption. It shifts with cyclization time $(\mathrm{t})$ towards the negative direction. Also, the cathodic peak $\left(\mathrm{II}_{\mathrm{c}}\right)$ shifts towards more negative values in the range -180 to $-230 \mathrm{mV}$, this indicates that the adsorption/desorption processes of oxygen becomes more feasible with the repetitive cycling. The relation between the number of cycles performed on the platinum electrode and the peak current densities of oxidation peak $\left(I_{a}\right)$ and reduction peak $\left(I_{c}\right)$ are shown in Fig. (2). 


\author{
Military Technical College \\ Kobry El-Kobbah, \\ Cairo, Egypt
}

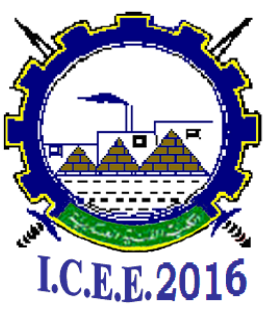

$8^{\text {th }}$ International Conferenc

on

Chemical \& Environmenta Engineering

19 - 21 April 2016

\subsubsection{Anodic and Cathodic Charges of Pt cyclization in $0.1 \mathrm{M} \mathrm{KOH}$}

The charge densities (milli coulomb per square centimeter) vs. the number of cycles were determined and are shown in Fig. (3), for both anodic peak and cathodic peak reactions. Charge associated with a cyclic voltammetry could be determined by manual technique of cutting and weighing the peaks and then taking the ratio of the peak weight to that of a rectangle of a known area and weight [8].

A comparison of the anodic and cathodic charge densities shows that they have not the same values. The difference is due to a slow reaction, except the unstable first cycle. A comparison of the charge curves also shows that the cathodic charge densities indicate that the electricity which used to remove the oxide is increased. This indicates that the initial adsorption rate grows with time increase as expected [9], due to activation of the surface by cyclization which enhances reduction of dissolved oxygen. In contrast for the anodic charges which decreased with the modification time indicating that the less electricity required for oxide formation, i.e., the oxide become easily formed.

\subsubsection{Characterization of oxide-promoted $\mathrm{Pt}$}

The conditions for complete monolayer oxide formation on platinum surfaces are important from a practical viewpoint as it forms the basis of a useful method for determining the true surface area (or roughness value) of the metal surface [10]. A measure of the real electrochemical surface area can be obtained from the charge corresponding to hydrogen reaction peak. It is assumed that each surface platinum atom is associated with one chemisorbed hydrogen atom. Thus,

$$
\mathrm{A}_{\mathrm{r}}=\mathrm{Q}_{\mathrm{h}} / \mathrm{Q}_{\mathrm{m}} \quad\left(\mu \mathrm{C} / \mu \mathrm{C} \cdot \mathrm{cm}^{-2}\right)
$$

Where, $A_{r}$ is the real electrochemical surface area $\left(\mathrm{cm}^{2}\right), Q_{h}$ is charge corresponding to the saturated hydrogen coverage on the electrode $(\mu \mathrm{C})$ and $\mathrm{Q}_{\mathrm{m}}$ is the charge associated with monolayer adsorption of hydrogen $\left(\mu \mathrm{C} \mathrm{cm}^{-2}\right)$. A theoretical charge of $\mathrm{Q}_{\mathrm{m}}=210 \mu \mathrm{C} \mathrm{\textrm {cm } ^ { - 2 }}$ was used for the conversion of the hydrogen adsorption charge to the real surface area [11]. The characteristic value of charge density associated with a monolayer of hydrogen adsorbed on polycrystalline platinum $\left(210 \mu \mathrm{C} / \mathrm{cm}^{2}\right)$ is widely used to determine the true (microscopic) surface area of Pt electrodes [12].

The ratio of the microscopic surface area to the geometric area $\left(\mathrm{A}_{\mathrm{m}} / \mathrm{A}_{\mathrm{g}}\right)$ gives the roughness factor $(F)$ [13]. In another account, roughness factor, $\mathrm{R}_{\mathrm{f}}$ describes the enhancement of the real electrochemical surface area in comparison with the geometric area, $\mathrm{A}_{\mathrm{g}}\left(\mathrm{cm}^{2}\right)[14]$.

$$
\mathrm{R}_{\mathrm{f}}=\mathrm{A}_{\mathrm{r}} / \mathrm{A}_{\mathrm{g}}
$$

It is worthwhile mention that $R_{f}$ is a measure for the relative number of active sites regarding a given process. These active sites were referred to it by roughness factor $\left(R_{f}\right)$ as superactive states. 
Military Technical College

Kobry El-Kobbah, Cairo, Egypt

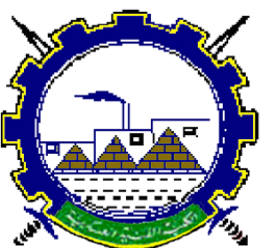

I.C.E.E.2016 $8^{\text {th }}$ International Conferenc

on

Chemical \& Environmenta Engineering

$19-21$ April 2016

Table 1, shows the roughness factor of the electrode is about 4 as obtained by estimating the hydrogen adsorption peak area, assuming that the monolayer charge density for hydrogen adsorption-desorption is $210 \mu \mathrm{C} \mathrm{cm}^{-2}$ [15]. Electrodes with rough surfaces are of great practical importance from both applied and fundamental points of view. The influence of electrode roughness on cyclic voltammetry was studied [16], using the diffusion domain approach which used to model cyclic voltammetry at such electrodes. It was found that, electrode roughness only has a significant effect on the shape of cyclic voltammograms and peak currents at relatively high values of electrode roughness.

Table 1: Roughness factor of oxide-supported platinum electrode as determined from the charge corresponding to the hydrogen adsorption peak in Fig. 1.

\begin{tabular}{cccc}
\hline $\begin{array}{c}\text { Time of } \\
\text { activation } \\
\text { (min.) }\end{array}$ & \multicolumn{3}{c}{ Parameters } \\
\cline { 2 - 4 } & $\begin{array}{c}\mathrm{Q}_{\mathrm{H}} \\
(\mathrm{mC})\end{array}$ & $\begin{array}{c}\mathrm{A}_{\mathrm{r}} \\
\left(\mathrm{cm}^{2}\right)\end{array}$ & $\mathrm{R}_{\mathrm{f}}$ \\
\hline 0.021 & 0.29 & 1.36 & 3.39 \\
\hline 0.042 & 0.3 & 1.43 & 3.57 \\
\hline 0.1 & 0.31 & 1.47 & 3.66 \\
\hline 0.21 & 0.32 & 1.5 & 3.75 \\
\hline 1 & 0.33 & 1.54 & 3.84 \\
\hline 5 & 0.34 & 1.61 & 4.02 \\
\hline 10 & 0.35 & 1.64 & 4.11 \\
\hline 15 & 0.36 & 1.73 & 4.32 \\
\hline
\end{tabular}

\subsection{Electrooxidation of Methanol in KOH}

For alcohols oxidation in alkaline solutions, the reaction current densities obtained during alcohol oxidation at certain potentials are at least an order of magnitude greater than in acidic electrolytes [17]. Methanol and ethanol are a popular alternative fuels for DAFCs, since methanol has higher theoretical energy density than the other alcohols and high miscibility to water in spite of its toxicity. Thus far, most investigations were devoted to direct methanol fuel cells (DMFCs) due to their simple fueling system design. It has been known for long times that the anodic oxidation of methanol in alkaline media is more feasible than in acidic media [18]. However, alkaline aqueous solutions are not stable for DMFC owing to carbonation. Unlike in acid, the electrode does not suffer severely from poisoning in alkalis because bonding of the chemisorbed intermediates on platinum is weak and the amount of the suggested poisoning species $\mathrm{CO}_{\mathrm{ads}}$, is smaller than in an acidic medium [19]. Platinum is generally considered the best monometallic catalyst for the electro-oxidation of 


\author{
Military Technical College \\ Kobry El-Kobbah, \\ Cairo, Egypt
}

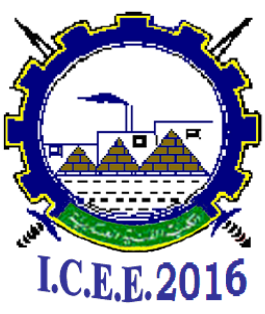

$8^{\text {th }}$ International Conferenc

on

Chemical \& Environmenta Engineering

$19-21$ April 2016

small organic molecules due to its capability to catalyze carbon hydrogen bond rupture as well as $\mathrm{CO}$ oxidation at comparatively low overpotential. With regard to the anode reaction, methanol oxidation on $\mathrm{Pt}$ produces $\mathrm{CO}$, formaldehyde, formic acid, etc., as reaction intermediates [20]. However, the strong adsorption of $\mathrm{CO}$ on the $\mathrm{Pt}$ surface during methanol oxidation rapidly diminishes the catalytic performance. So, platinum is the preferred catalyst for direct methanol fuel cell in alkaline media due to the absence of poisoning by adsorbed carbon monoxide which plays a significant role in methanol oxidation. The present study involves modification of platinum by repetitive cycling to produce hydrated oxide film to minimize the poisoning effect of $\mathrm{CO}$.

\subsubsection{Effect of Methanol concentration in $0.1 \mathrm{M} \mathrm{KOH:}$}

The cyclic voltammetric behavior of electro-oxidation of methanol on a modified Pt electrode surface in $0.1 \mathrm{M} \mathrm{KOH}$ is shown in Fig. (4). The potential sweeps are for methanol oxidation on a modified platinum electrode after 15 minutes of modification in $0.1 \mathrm{M} \mathrm{KOH}$ solution in absence and presence of different concentrations of methanol over the range from 0.1 to 0.5 M. The CVs were performed between -400 and $400 \mathrm{mV}$ at a scan rate of $50 \mathrm{mV} \mathrm{s}^{-1}$, at room temperature. As can be seen, in the potential range from -400 to $400 \mathrm{mV}$, there are no peaks in $0.1 \mathrm{M} \mathrm{KOH}$ solution without any alcohol but in the presence of methanol an anodic peak $\left(\mathrm{I}_{\mathrm{a}}\right)$ appears with a broad shoulder in the potential region of about $200 \mathrm{mV}$ vs. SCE and a backward anodic peak $\left(\mathrm{II}_{\mathrm{a}}\right)$ exists in the potential range from 100 to $50 \mathrm{mV}$. Thus, a single oxidation peak, centered at $200 \mathrm{mV}$ vs. SCE appears upon an anodic sweep; however, when the $\mathrm{CV}$ sweep is reversed towards the $\mathrm{H}_{2}$ reversible potential, another oxidation peak (centered at $75 \mathrm{mV}$ ) emerges in the voltammetric profile.

Comparison of these curves demonstrates that the current density is higher in the presence of methanol and increase by increasing the methanol concentration. For methanol oxidation, both liquid products formaldehyde and formate can be formed [21].

The most obvious voltammetric characteristic of the methanol oxidation at the modified $\mathrm{Pt}$ electrode is that the CVs recorded display a large oxidation peak (primary oxidation peak) at $200 \mathrm{mV}$ in the forward anodic scan and another oxidation peak (secondary oxidation peak) around $75 \mathrm{mV}$ in the backward cathodic scan, Fig. (4). Plots of the logarithm of current densities $\left(\log \mathrm{j}_{\mathrm{p}}\right)$ vs. the logarithm of the concentrations of methanol for each anodic and reverse anodic peak on the modified Pt electrode surface are given in Fig. (5).

\subsubsection{Effect of Methanol concentration in $0.05 \mathrm{M} \mathrm{KOH:}$}

The effect of concentration of methanol in the range from 0.05 to $0.2 \mathrm{M}$ on its oxidation on the modified Pt electrode in $0.05 \mathrm{M} \mathrm{KOH}$ is investigated by CVs, Fig. (6). It shows the CVs for the potential range from -400 to $400 \mathrm{mV}$, the peak potential has a continuous negativeshift with an increase in the methanol concentration. Furthermore, the peak current is observed to increase as the methanol concentration increases from 0.05 to $0.2 \mathrm{M}$, i.e., the oxidation current increases as the methanol concentration increases. Comparing the results in 


\author{
Military Technical College \\ Kobry El-Kobbah, \\ Cairo, Egypt
}

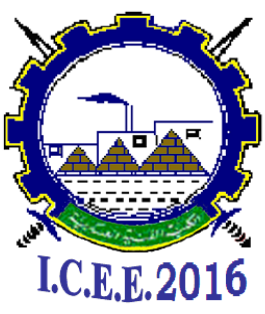

$8^{\text {th }}$ International Conferenc

on

Chemical \& Environmenta Engineering

$19-21$ April 2016

$0.1 \mathrm{M} \mathrm{KOH}$ with those in $0.05 \mathrm{M}$ reveals that the later is more efficient possibly due to the competitive adsorption between the hydroxide ions and methanol [22]. Furthermore, the peak potential has a continuous negative-shift with the increasing of methanol concentration. Fig. (7), shows the relation between the logarithm of current densities $\left(\log j_{p}\right)$ vs. the logarithm of the concentrations of methanol for each anodic and reversible anodic peak on the modified $\mathrm{Pt}$ electrode surface at the same conditions. It is found that the oxidation current density of methanol increases with the increase of its concentration, the maximum current density was achieved at $0.2 \mathrm{M}$ methanol.

The negative going of the peak potential suggests that the dilution of $\mathrm{KOH}$ has a favorable effect on the oxidation of methanol in addition to methanol concentration. It is indicated that at first the alcohol oxidation reaction on the modified Pt electrode can be accelerated at lower $\mathrm{OH}^{-}$concentrations that lead to an increase in the anodic peak current, but at higher $\mathrm{KOH}$ concentrations, the adsorption of hydroxyl ions may be dominant on the modified $\mathrm{Pt}$ electrode, that blocking the adsorption of alcohol on the electrode. Such imbalances lead to a decrease in the anodic peak current [22].

\subsubsection{Mechanism of Methanol Oxidation:}

The oxidation mechanisms of methanol have been widely studied in alkaline media with cyclic voltammetry $[18,23]$. The oxidation products observed at platinum are formaldehyde and formate [21]. However, the disadvantage of purely electrochemical methods is that no information on the adsorbents or the oxidation products is obtained. Therefore, several spectroscopic methods, such as Fourier Transform Infrared Spectroscopy (FTIRS) [24,25], Surface Enhanced Raman Spectroscopy [26] and Differential Electrochemical Mass Spectrometry [27], have been applied to probe reaction intermediates and mechanisms. With these methods (volatile) reaction products and/or adsorbed species can be probed. $\mathrm{CO}_{2}$ is the main product as no further carbon cleavage is required.

The mechanism of electrochemical oxidation of methanol on platinum in alkaline systems involves formation of adsorbed methanolic species and $\mathrm{OH}$ on the Pt surface. The oxidation takes place through a series of reaction steps involving successive electron transfer, i.e. partial oxidation, to form adsorbed species. These react with adsorbed $\mathrm{OH}$ to form carbon dioxide. The reaction mechanism has been written as follows [19]:

$$
\begin{aligned}
& \mathrm{Pt}+\mathrm{OH}^{-} \rightarrow \mathrm{Pt}-(\mathrm{OH})_{\text {ads }}+\mathrm{e}^{-} \\
& \mathrm{Pt}+\left(\mathrm{CH}_{3} \mathrm{OH}\right)_{\mathrm{sol}} \rightarrow \mathrm{Pt}-\left(\mathrm{CH}_{3} \mathrm{OH}\right)_{\mathrm{ads}} \\
& \mathrm{Pt}-\left(\mathrm{CH}_{3} \mathrm{OH}\right)_{\mathrm{ads}}+\mathrm{OH}^{-} \rightarrow \mathrm{Pt}-\left(\mathrm{CH}_{3} \mathrm{O}\right)_{\mathrm{ads}}+\mathrm{H}_{2} \mathrm{O}+\mathrm{e}^{-} \\
& \mathrm{Pt}-\left(\mathrm{CH}_{3} \mathrm{O}\right)_{\mathrm{ads}}+\mathrm{OH}^{-} \rightarrow \mathrm{Pt}-\left(\mathrm{CH}_{2} \mathrm{O}\right)_{\mathrm{ads}}+\mathrm{H}_{2} \mathrm{O}+\mathrm{e}^{-} \\
& \mathrm{Pt}-\left(\mathrm{CH}_{2} \mathrm{O}\right)_{\mathrm{ads}}+\mathrm{OH}^{-} \rightarrow \mathrm{Pt}-(\mathrm{CHO})_{\mathrm{ads}}+\mathrm{H}_{2} \mathrm{O}+\mathrm{e}^{-} \\
& \mathrm{Pt}-(\mathrm{CHO})_{\mathrm{ads}}+\mathrm{OH}^{-} \rightarrow \mathrm{Pt}-(\mathrm{CO})_{\mathrm{ads}}+\mathrm{H}_{2} \mathrm{O}+\mathrm{e}^{-} \\
& \mathrm{Pt}-(\mathrm{CHO})_{\mathrm{ads}}+\mathrm{Pt}-(\mathrm{OH})_{\mathrm{ads}}+2 \mathrm{OH}^{-} \rightarrow 2 \mathrm{Pt}+\mathrm{CO}_{2}+2 \mathrm{H}_{2} \mathrm{O}+2 \mathrm{e}^{-} \\
& \mathrm{Pt}-(\mathrm{CHO})_{\mathrm{ads}}+\mathrm{Pt}-(\mathrm{OH})_{\mathrm{ads}}+\mathrm{OH}^{-} \rightarrow \mathrm{Pt}+\mathrm{Pt}-(\mathrm{COOH})_{\mathrm{ads}}+\mathrm{H}_{2} \mathrm{O}+\mathrm{e}^{-}
\end{aligned}
$$




\author{
Military Technical College \\ Kobry El-Kobbah, \\ Cairo, Egypt
}

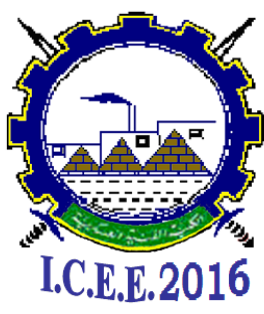

$8^{\text {th }}$ International Conferenc

on

Chemical \& Environmenta Engineering

$19-21$ April 2016

$$
\begin{aligned}
& \mathrm{Pt}-(\mathrm{CO})_{\mathrm{ads}}+\mathrm{Pt}-(\mathrm{OH})_{\mathrm{ads}}+\mathrm{OH}^{-} \rightarrow 2 \mathrm{Pt}+\mathrm{CO}_{2}+\mathrm{H}_{2} \mathrm{O}+\mathrm{e}^{-} \\
& \mathrm{Pt}-(\mathrm{CO})_{\mathrm{ads}}+\mathrm{Pt}-(\mathrm{OH})_{\mathrm{ads}} \leftrightarrow \mathrm{Pt}+\mathrm{Pt}-(\mathrm{COOH})_{\mathrm{ads}} \\
& \mathrm{Pt}-(\mathrm{COOH})_{\mathrm{ads}}+\mathrm{OH}^{-} \rightarrow \mathrm{Pt}-(\mathrm{OH})_{\mathrm{ads}}+\mathrm{HCOO}^{-} \\
& \mathrm{Pt}-(\mathrm{COOH})_{\mathrm{ads}}+\mathrm{Pt}-(\mathrm{OH})_{\mathrm{ads}} \rightarrow 2 \mathrm{Pt}+\mathrm{CO}_{2}+\mathrm{H}_{2} \mathrm{O}
\end{aligned}
$$

The rate-determining step is most likely the reaction with the oxidation of the active intermediate- $\mathrm{CHO}[28]$.

The ratio of the forward anodic peak current $\left(\mathrm{I}_{f}\right)$ to the reverse anodic peak current $\left(\mathrm{I}_{b}\right), \mathrm{I}_{f} / \mathrm{I}_{b}$, may be used to evaluate the tolerance of catalyst to carbonaceous species accumulation. The higher the $\mathrm{I}_{f} / \mathrm{I}_{b}$ ratio, the stronger the catalyst tolerance to catalyst poisons [29]. The relative high $\mathrm{I}_{f} / \mathrm{I}_{b}$ ratio $(\sim 1.2-1.5)$ indicates good tolerance of the modified $\mathrm{Pt}$ as a catalyst to CO-like intermediate species in $0.1 \mathrm{M} \mathrm{KOH}$ and it raises for modified $\mathrm{Pt}$ in $0.05 \mathrm{M} \mathrm{KOH}$ to be $(\sim 1.3-$ 2.2).

\subsection{Electro-oxidation of Ethanol in $\mathrm{KOH}$}

Alcohols of higher molar mass, such as ethanol and iso-propanol, are less toxic, have higher boiling points and energy densities, making them interesting options for DAFC. EtOH, which is easily derived in large quantity via fermentation of biomass, is a green, sustainable, carbonneutral fuel. Additionally, in comparison to $\mathrm{MeOH}, \mathrm{EtOH}$ is non-toxic and its boiling point is relatively higher. In this respect, fuel cells running on $\mathrm{EtOH}$ - direct EtOH fuel cells (DEFCs) represent a promising choice for sustainable energy conversion, and have been drawn a great deal of attention [24,30-33]. Several studies have examined EtOH crossover [30,32,33], and its effect on mixed potential formation in DEFCs [31].

The required faster kinetics of the ethanol oxidation and especially for the oxygen reduction reaction seems to be satisfied if working at low temperature values. Finally, it is worth to be noticed that the best value ever reported has been obtained in a very promising alkaline-acid direct ethanol fuel cell (AA-DEFC) [34].

The ethanol oxidation reaction in alkaline media has been much less studied, mainly due to the impracticalities that lie in the utilization of alkaline fuel cells [35]. One important issue is that an alkaline electrolyte is prone to progressive carbonation due to $\mathrm{CO}_{2}$ retention, deactivating the electrolyte over time.

\subsubsection{Effect of Ethanol concentration in $0.1 \mathrm{M} \mathrm{KOH:}$}

The $\mathrm{CV}$ of the modified Pt electrode in the solution of $0.1 \mathrm{M} \mathrm{KOH}$ containing different concentrations of ethanol ranging from 0.05 to $0.5 \mathrm{M}$ is given, Fig. (8). It is clearly seen that the oxidation of the ethanol commences at about $0.1 \mathrm{~V}$, an oxidation peak $\left(\mathrm{I}_{\mathrm{a}}\right)$ appears at $0.2 \mathrm{~V}$ 


\author{
Military Technical College \\ Kobry El-Kobbah, \\ Cairo, Egypt
}

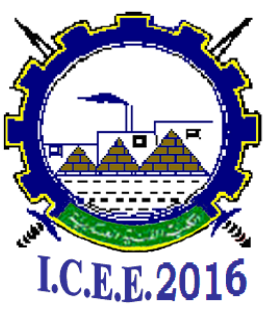

$8^{\text {th }}$ International Conferenc

on

Chemical \& Environmenta Engineering

$19-21$ April 2016

during positive potential scanning. In addition, a re-oxidation peak $\left(\mathrm{II}_{\mathrm{a}}\right)$ is detected at about $0.12 \mathrm{~V}$ in the reverse scan. It is clear that the oxidation of ethanol is characterized by two well-oxidation peaks in the forward and reverse scans. While the latter peak is typically attributed to the process of oxidation of surface-adsorbed $\mathrm{CO}_{\mathrm{ads}}$ species, the former one is usually assigned to the formation of acetaldehyde [36,37]. Moreover, electro-oxidation of ethanol on the modified Pt surface takes part in parallel with the process of UPD of $\mathrm{H}$, which arises in alkaline media at Pt over the potential range $0.2 \mathrm{~V}$ vs. SCE. However, it can be seen in the respective $\mathrm{CV}$ profile of Fig. (8), that a 10-fold increase of ethanol concentration (from 0.05 to $0.5 \mathrm{M} \mathrm{C}_{2} \mathrm{H}_{5} \mathrm{OH}$ ) resulted in significantly intensified voltammetric current-densities.

The onset potential of ethanol oxidation on the modified Pt electrode is $80 \mathrm{mV}$ more negative than that of the methanol oxidation, the current densities of ethanol oxidation peak in the positive potential scanning is $0.73-7.74 \mathrm{~mA} . \mathrm{cm}^{-2}$ which is higher than that of the methanol oxidation under the same conditions. Possibly due to the stronger adsorption of methanol compared to ethanol.

The results indicate that the oxygen species such as $\mathrm{O}_{a d}$ results from the modification of $\mathrm{Pt}$ electrode have crucial role in electro-oxidation of ethanol, the activity of alcohol oxidation mainly due to the synergistic effect by the interaction among $\mathrm{O}_{\mathrm{ad}}$ and the alcohol. The $\mathrm{O}_{\mathrm{ad}}$ acted as an efficient supporting material for electro-oxidation of alcohols, which is a promising field of research. Plots of the logarithm of current densities $\left(\log j_{p}\right)$ vs. the logarithm of the concentrations of ethanol for each anodic and reverse anodic peaks on the modified Pt electrode surface are given in Fig. (9).

\subsubsection{Effect of Ethanol concentration in $0.05 \mathrm{M} \mathrm{KOH:}$}

The CVs of the modified Pt electrode in $0.05 \mathrm{M} \mathrm{KOH}$ solution in absence and presence of different ethanol concentrations ranging from 0.05 to $0.2 \mathrm{M}$, at the same conditions, are shown in Fig. (10). It is found that the oxidation current of ethanol has a similar behavior which monotonically increases as the alcohol concentration increases. Furthermore, the peak potential of ethanol has a continuous negative-shift with the increase in its concentration. Further increase in $\mathrm{KOH}$ concentration quickly depressed the anodic peak current. In $0.1 \mathrm{M}$ $\mathrm{KOH}$ concentration, the alcohol concentration and the coverage of $\mathrm{OH}^{-}$are independent on each other. As the alcohol concentration increase, the adsorption of alcohol on the catalyst will be dominant, and the adsorption of the hydroxyl ions will thus be largely blocked, so lead to the decrease of anodic peak current, on the contrary in $0.05 \mathrm{M} \mathrm{KOH}$ concentration.

The concentration of alcohol also has impact on the oxidation of ethanol in $0.05 \mathrm{M} \mathrm{KOH}$. Also, the oxidation current of ethanol oxidation on the modified Pt electrode is much higher than that of methanol oxidation, at the same conditions.

The relationship between the ethanol concentration and the peak current density in both forward and reverse scanning obtained for ethanol oxidation are plotted in Fig. (11). 
Military Technical College

Kobry El-Kobbah,

Cairo, Egypt

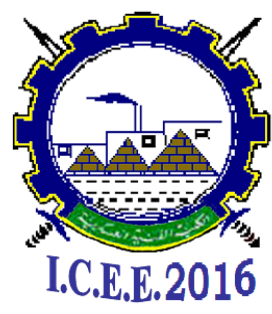

$8^{\text {th }}$ International Conferenc

on

Chemical \& Environmenta

Engineering

$19-21$ April 2016

\subsubsection{The Mechanism of Ethanol Oxidation:}

An interesting example is the oxidation of carbon monoxide, a well studied model reaction as well as an intermediate in the complete oxidation of ethanol. Interestingly, the oxidation of $\mathrm{CO}$ in alkaline media occurs at smaller over-potentials compared to acidic media [38], even on the reversible hydrogen electrode (RHE) scale, which should correct for 'trivial' $\mathrm{pH}$ effects. In addition, in the case of the ethanol oxidation reaction, it has been found that changing electrolyte $\mathrm{pH}$ also changes the product distribution. Despite the clear advantages of employing an alkaline electrolyte for the ethanol oxidation reaction, there is still no clear mechanistic understanding of the reaction in alkaline media.

The Electrochemical oxidation of ethanol in alkaline media can be presented as [17]:

$$
\begin{aligned}
& \mathrm{CH}_{3} \mathrm{CH}_{2} \mathrm{OH}+2 \mathrm{OH}^{-} \rightarrow \mathrm{CH}_{3} \mathrm{CHO}+2 \mathrm{H}_{2} \mathrm{O}+2 \mathrm{e}^{-} \\
& \mathrm{CH}_{3} \mathrm{CH}_{2} \mathrm{OH}+4 \mathrm{OH}^{-} \rightarrow \mathrm{CH}_{3} \mathrm{COOH}+3 \mathrm{H}_{2} \mathrm{O}+4 \mathrm{e}^{-} \\
& \mathrm{CH}_{3} \mathrm{CH}_{2} \mathrm{OH}+12 \mathrm{OH}^{-} \rightarrow 2 \mathrm{CO}_{2}+9 \mathrm{H}_{2} \mathrm{O}+12 \mathrm{e}^{-}
\end{aligned}
$$

Ideally, the electrochemical EtOH oxidation reaction (EOR) would produce twelve electrons per molecule of ethanol. The reaction at low temperature leads to a low Faradic efficiency.

For ethanol oxidation in alkaline media, the formation of acetaldehyde or acetic acid was identified [39]. The steps involved can be presented as:

$$
\begin{aligned}
& \mathrm{M}+\mathrm{OH}^{-} \rightarrow \mathrm{M}-\mathrm{OH}_{\mathrm{ads}}+\mathrm{e}^{-} \\
& \mathrm{M}+\mathrm{CH}_{3} \mathrm{CH}_{2} \mathrm{OH} \rightarrow \mathrm{M}-\left(\mathrm{CH}_{3} \mathrm{CH}_{2} \mathrm{OH}\right)_{\mathrm{ads}} \\
& \mathrm{M}-\left(\mathrm{CH}_{3} \mathrm{CH}_{2} \mathrm{OH}\right)_{\mathrm{ads}}+3 \mathrm{OH}^{-} \rightarrow \mathrm{M}-\left(\mathrm{CH}_{3} \mathrm{CO}\right)_{\mathrm{ads}}+3 \mathrm{H}_{2} \mathrm{O}+3 \mathrm{e}^{-} \\
& \mathrm{M}-\left(\mathrm{CH}_{3} \mathrm{CO}\right)_{\mathrm{ads}}+\mathrm{M}-\mathrm{OH}_{\mathrm{ads}} \rightarrow \mathrm{M}-\mathrm{CH}_{3} \mathrm{COOH}+\mathrm{M} \\
& \mathrm{M}-\mathrm{CH}_{3} \mathrm{COOH}+\mathrm{OH}^{-} \rightarrow \mathrm{M}+\mathrm{CH}_{3} \mathrm{COO}^{-}+\mathrm{H}_{2} \mathrm{O} \\
& \mathrm{M}=\mathrm{Au} \text { or Pd. }
\end{aligned}
$$

The rate-determining step is eq. (22), in which the adsorbed ethoxy intermediate is removed by adsorbed hydroxyl ions to form acetate [34]. Fang et al., studied the mechanism of ethanol electro-oxidation on a palladium electrode in alkaline solution with various concentrations of $\mathrm{NaOH}(0.01$ to $5 \mathrm{M})$ [25]. It has been found that, the highest activity was attributed to $\mathrm{OH}_{\mathrm{ads}}$ species. Also, the density functional theory (DFT) calculations show that in acidic media continued dehydrogenation of ethanol is difficult due to the lack of $\mathrm{OH}$ species to instantly remove hydrogen, while in alkaline media, ethanol and sufficient $\mathrm{OH}$ can be adsorbed on $\mathrm{Pd}$ leading to continuous oxidation.

The $\mathrm{I}_{f} / \mathrm{I}_{b}$ ratio $(\sim 1.1-1.3)$ for the modified $\mathrm{Pt}$ in $0.1 \mathrm{M} \mathrm{KOH}$ and it becomes $(\sim 1.2-1.7)$ in 0.05 $\mathrm{M} \mathrm{KOH}$ indicates that the good tolerance of the modified $\mathrm{Pt}$ as a catalyst to CO-like intermediate species in $0.05 \mathrm{M} \mathrm{KOH}$ than in $0.1 \mathrm{M} \mathrm{KOH}$. 
Military Technical College

Kobry El-Kobbah,

Cairo, Egypt

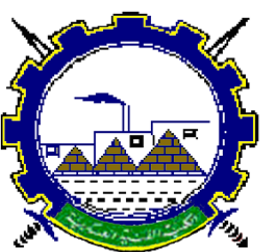

I.C.E.E.2016 $8^{\text {th }}$ International Conferenc

on

Chemical \& Environmenta

Engineering

19 -21 April 2016

\subsection{Quantity of Electricity Curves:}

The charge densities $\mathrm{Q}$ deduced from the anodic peak $\left(\mathrm{I}_{\mathrm{a}}\right)$ of $\mathrm{CV}$ curves are presented in Fig. (12), for different methanol concentrations over the range $0.1-0.5 \mathrm{M}$ after 15 minutes of $\mathrm{Pt}$ modification in $0.1 \mathrm{M} \mathrm{KOH}$. It was found that the charge density is dependent of the methanol concentration. The increase in concentration of methanol increases the charge corresponding to methanol oxidation at the modified Pt electrode. Also, the same calculations are made for methanol concentrations over the range $0.05-0.2 \mathrm{M}$ in $0.05 \mathrm{M} \mathrm{KOH}$ after 15 minutes of $\mathrm{Pt}$ modification, Fig. (13). In case of $0.05 \mathrm{M} \mathrm{KOH}$, the charge density found to be 2 times higher than that of $0.1 \mathrm{M} \mathrm{KOH}$ which confirm the more feasible oxidation of methanol in $0.05 \mathrm{M}$ $\mathrm{KOH}$.

Almost the same behavior is observed for ethanol electro-oxidation, Figs. $(14,15)$. The charge density is a good criteria for revealing the extent of oxidation of the fuel under a given condition.

\section{Conclusions}

This study demonstrates the feasibility of applying a modified Pt electrode for electrooxidation of methanol and ethanol in alkaline media. Modification involves the formation of a hydrated surface oxide film. The surface electrocatalytic activity of the film strongly depends on the conditions, such as $\mathrm{KOH}$ concentration and modification time.

The onset potentials decrease and the current densities for electro-oxidation of methanol increase with increase of its concentrations. This effect is more pronounced for ethanol especially in $0.05 \mathrm{M} \mathrm{KOH}$ as compared to that in $0.1 \mathrm{M} \mathrm{KOH}$.

These results suggest that the modified Pt electrode is a good catalyst for the alcohol electro-oxidation, which we ascribe to the higher ability of platinum to oxidize the $\mathrm{CO}_{\mathrm{ads}}$ intermediate, since $\mathrm{CO}$ poisoning can be avoided.

\section{References}

[1] C. G. Lee, M. Umeda and I. Uchida, J. Power Sources, 160 (2006) 78.

[2] H. Y. Eileen, K. Scott and R. W. Reeve, J. Electroanal. Chem., 547 (2003) 17.

[3] J. P. Liu, J. Q. Ye, C. W. Xu, S. P. Jiang and Y. X. Tong, Electrochem. Commun., 9 (2007) 2334. 
Military Technical College

Kobry El-Kobbah,

Cairo, Egypt

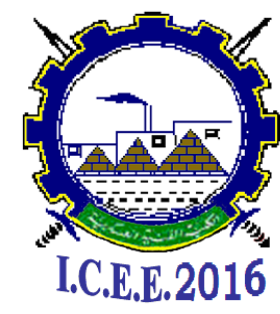

$8^{\text {th }}$ International Conferenc

on

Chemical \& Environmenta Engineering

$19-21$ April 2016

[4] Z. Borkowska, A. Tymosiak-Zielinska and G. Shul, Electrochim. Acta, 49 (2004) 1209.

[5] E. Gulzow, J. Power Source, 61 (1996) 99-104.

[6] Y. Wang, L. Li, L. Hu, L. Zhuang, J. Lu and B. Xu, Electrochem. Commun., 5 (2003) 662-666.

[7] A. Damjanovic, L-S. R. Yeh and J. F. Wolf, The Electrochemical Society, III . pH Dependence, 129 (1981) 2232.

[8] Omar A. Hazzazi, Ph-D-thesis "Electrochemical studies of metal deposition and surface chirality at well-defined platinum single crystal electrodes", University of Wales, (2002) p:148.

[9] S. V. Kalcheva and P. I. Iotov, Bull. Electrochem., 17 (2001) 351-356.

[10] J. M. D. Rodriguez, J. A. H. Melian and J. P. Pena, J. Chem. Educ., 9 (2000) 1195.

[11] V. S. Bogotzky and Y. B. Vassilyev, Electrochim. Acta, 12 (1967) 1323.

[12] S. Trasatti and O. A. Petrii, Pure Appl. Chem., 63 (1991) 711.

[13] A. J. Bard and L. R. Faulkner, Electrochemical Methods: Fundamentals and Applications; John Wiley \& Sons, Inc.: New York, (2001).

[14] Sagar Sen Gupta and Jayati datta, J. Chem. Sci., Vol. 117, No. 4, (2005) 337-344.

[15] A. Miki, S. Ye and M. Osawa, Chem. Commun., 14 (2002) 1500.

[16] Denis Menshykau, Ian Streeter and Richard G. Compton, J. Phys. Chem. C, 112 (37), (2008), pp 14428-14438.

[17] Eileen Hao Yu, Ulrike Krewer and Keith Scott, Energies, 3 (2010) 1499-1528.

[18] A. Tripkovic, K. Popovic, B. Grgur, B. Blizanac, P. Ross and N. Markovic, Electrochim. Acta, 47 (2002) 3707.

[19] B. Beden, J. M. Léger and C. Lamy, In Modern Aspects of Electrochemistry; Bockris J. O. M., Conway B. E., White R. E., Eds.; Plenum Press: New York, NY, USA, (1992), Volume 22, p. 97.

[20] G. T. Burstein, C. J. Barnett, A. R. Kucernak and K. R. Williams, Catal. Today, 38 (1997) 425.

[21] Annukka Santasalo-Aarnio, Youngkook Kwon, Elisabet Ahlberg, Kyosti Kontturi, Tanja Kallio and Marc T. M. Koper, Electrochemistry Communications, 13 (2011) 466469.

[22] Z. X. Liang, Zhao T. S., Xu J. B. and Zhu L. D., Electrochimica Acta, 54 (2009) 22032208.

[23] A. Santasalo, F. J. Vidal-Iglesias, J. Solla-Gullon, A. Berna, T. Kallio and J. M. Feliu, Electrochim. Acta, 54 (2009) 6576.

[24] Z. Y. Zhou, N. Tian, Y. J. Chen, S. P. Chen and S. G. Sun, J. Electroanal. Chem., 573 (2004) 111.

[25] X. Fang, L. Wang, P. K. Shen, G. Cui and C. Bianchini, J. Power Sources, 195 (2010) 1375.

[26] S. C. S. Lai and M. T. M. Koper, Phys. Chem. Chem. Phys., 11 (2009) 10446.

[27] D. Bayer, S. Berenger, M. Joos, C. Cremers and J. Tübke, Int. J. Hydr. En., 35 (2010) 12660. 
Military Technical College Kobry El-Kobbah, Cairo, Egypt

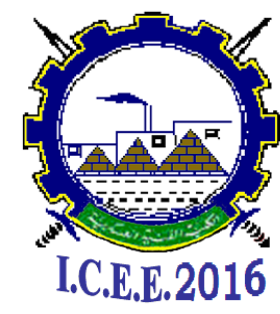

$8^{\text {th }}$ International Conferenc

on

Chemical \& Environmenta Engineering $19-21$ April 2016

[28] A. V. Tripkovic, K. D. Popovic, J. D. Momcilovic and D. M. Drazic, J. Electroanal. Chem., 448 (1998) 173-181.

[29] Cuicui Qiu, Ran Shang, Yafei Xie, Yanru Bu, Chunyun Li and Houyi Ma, Materials Chemistry and Physics, 120 (2010) 323-330.

[30] S. Song, W. Zhou, Z. Liang, R. Cai, G. Sun, Q. Xin, V. Stergiopoulos and P. Tsiakaras, Appl. Catal. B, 55(1) (2005) 65-72.

[31] G. M. Andreadis, A. K. M. Podias and P. E. Tsiakaras, J. Power Sources, 194(1) (2009) 397-407.

[32] H. Maab and S. P. Nunes, J. Power Sources, 195(13) (2010) 4036-4042.

[33] G. Andreadis and P. Tsiakaras, Chem. Eng. Sci., 61(22) (2006) 7497-7508.

[34] A. Brouzgou, A. Podias and P. Tsiakaras, J. Appl. Electrochem., (2013) 43:119-136.

[35] D. M. Dos Anjos, K. B. Kokoh, J. M. Léger, A. R. De Andrade, P. Olivi and G. Tremiliosi, J. Appl. Electrochem., 36 (2006) 1391-1397.

[36] A. A. Abd-El-Latif, E. Mostafa, S. Huxter, G. Attard and H. Baltruschat, Electrochim. Acta, 55 (2010) 7951.

[37] J. F. Gomes, B. Busson, A. Tadjeddine and G. Tremiliosi-Filho, Electrochim. Acta, 53 (2008) 6899.

[38] G. García and M. T. M Koper, Phys. Chem. Chem. Phys., 10 (2008) 3802-3811.

[39] [39] N. Fujiwara, Z. Siroma, S. I. Yamazaki, T. Ioroi, H. Senoh and K. Yasuda, J. Power Source, 185 (2008) 621-626. 
Military Technical College

Kobry El-Kobbah,

Cairo, Egypt

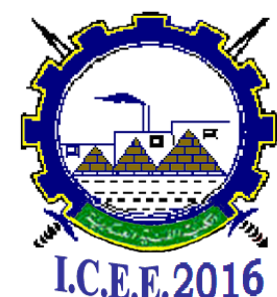

I.C.E.E. 2016 $8^{\text {th }}$ International Conferenc

on

Chemical \& Environmenta Engineering

$19-21$ April 2016

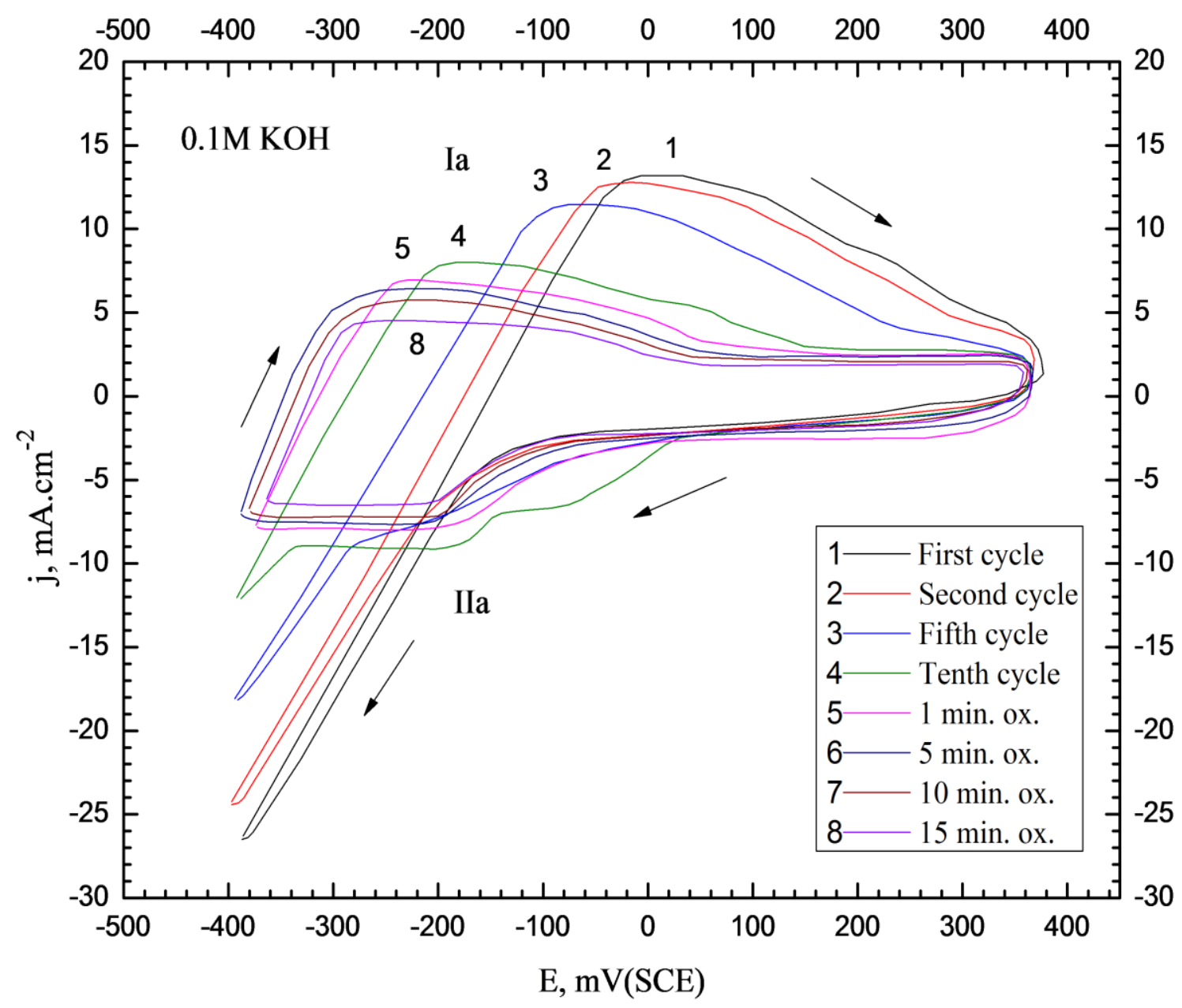

Fig. 1. Cyclic voltammogram of Pt electrode in $0.1 \mathrm{M} \mathrm{KOH}$ at $2000 \mathrm{mV} \mathrm{s} \mathrm{s}^{-1}$, for different times at $25^{\circ} \mathrm{C}$ 
Military Technical College

Kobry El-Kobbah,

Cairo, Egypt

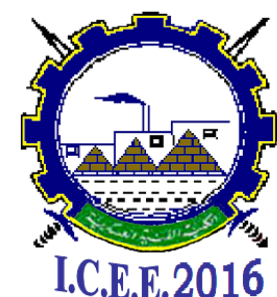

I.C.E.E.2016 $8^{\text {th }}$ International Conferenc

on

Chemical \& Environmenta Engineering

$19-21$ April 2016

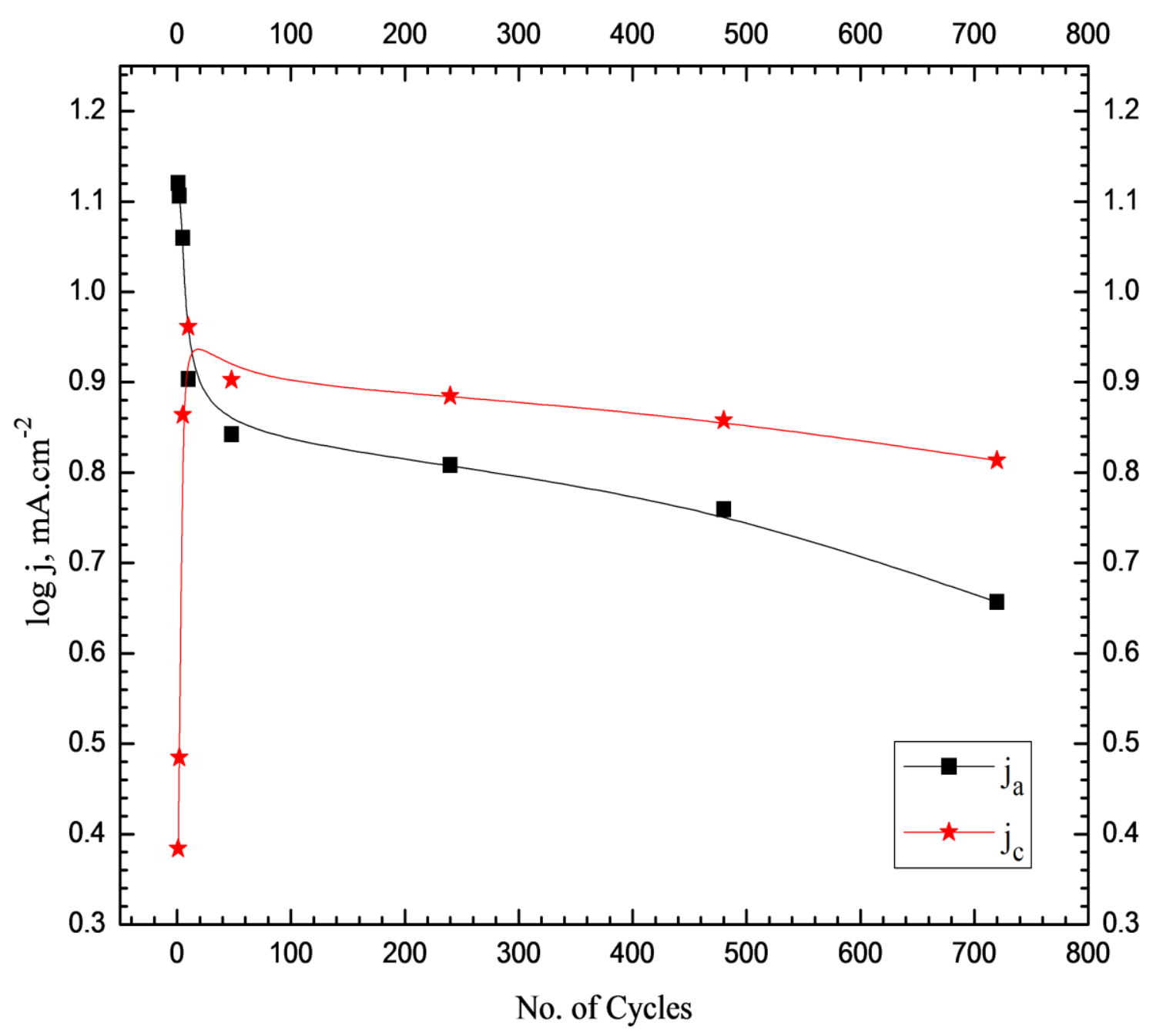

Fig. 2. Plots of no. of cycles vs. logarithm of the absolute value current density (peak $I_{a}$ and peak $\mathrm{II}_{\mathrm{c}}$ ) for Pt in $0.1 \mathrm{M} \mathrm{KOH}$. 
Military Technical College Kobry El-Kobbah, Cairo, Egypt

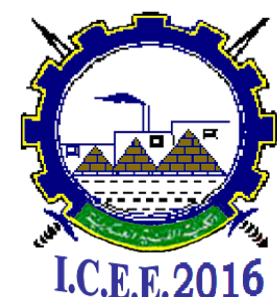

I.C.E.E.2016 $8^{\text {th }}$ International Conferenc

on

Chemical \& Environmenta Engineering

$19-21$ April 2016

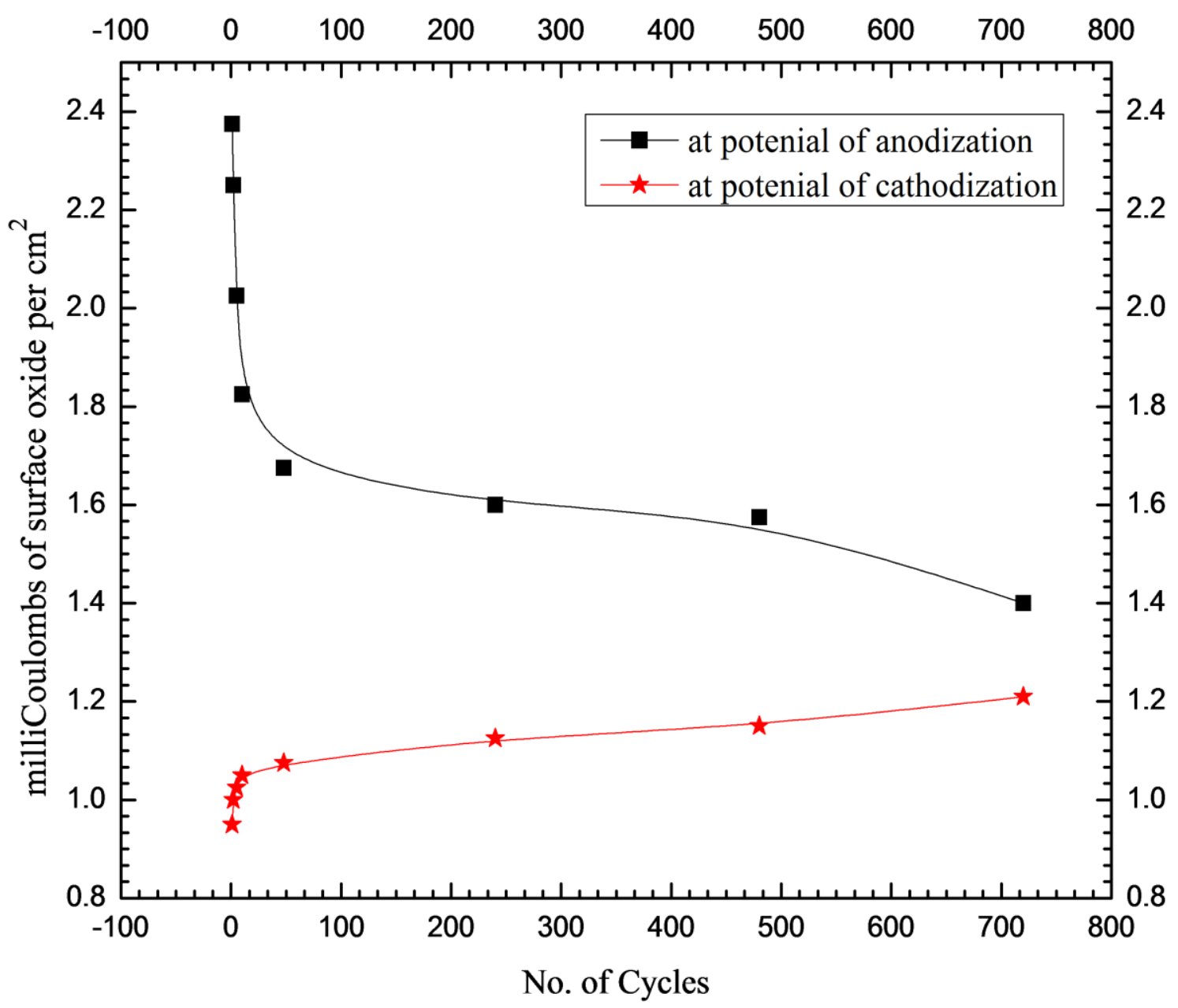

Fig. 3. Charge density vs. No. of cycles for both anodic $\left(\right.$ Peak $\left.I_{a}\right)$ and cathodic $\left(P e a k I_{c}\right)$ reactions of $\mathrm{Pt}$ in $0.1 \mathrm{M} \mathrm{KOH}$. 
Military Technical College Kobry El-Kobbah,

Cairo, Egypt

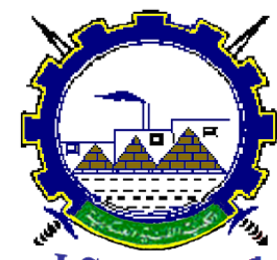

I.C.E.E. 2016

\section{$8^{\text {th }}$ International Conferenc \\ on}

Chemical \& Environmenta Engineering $19-21$ April 2016

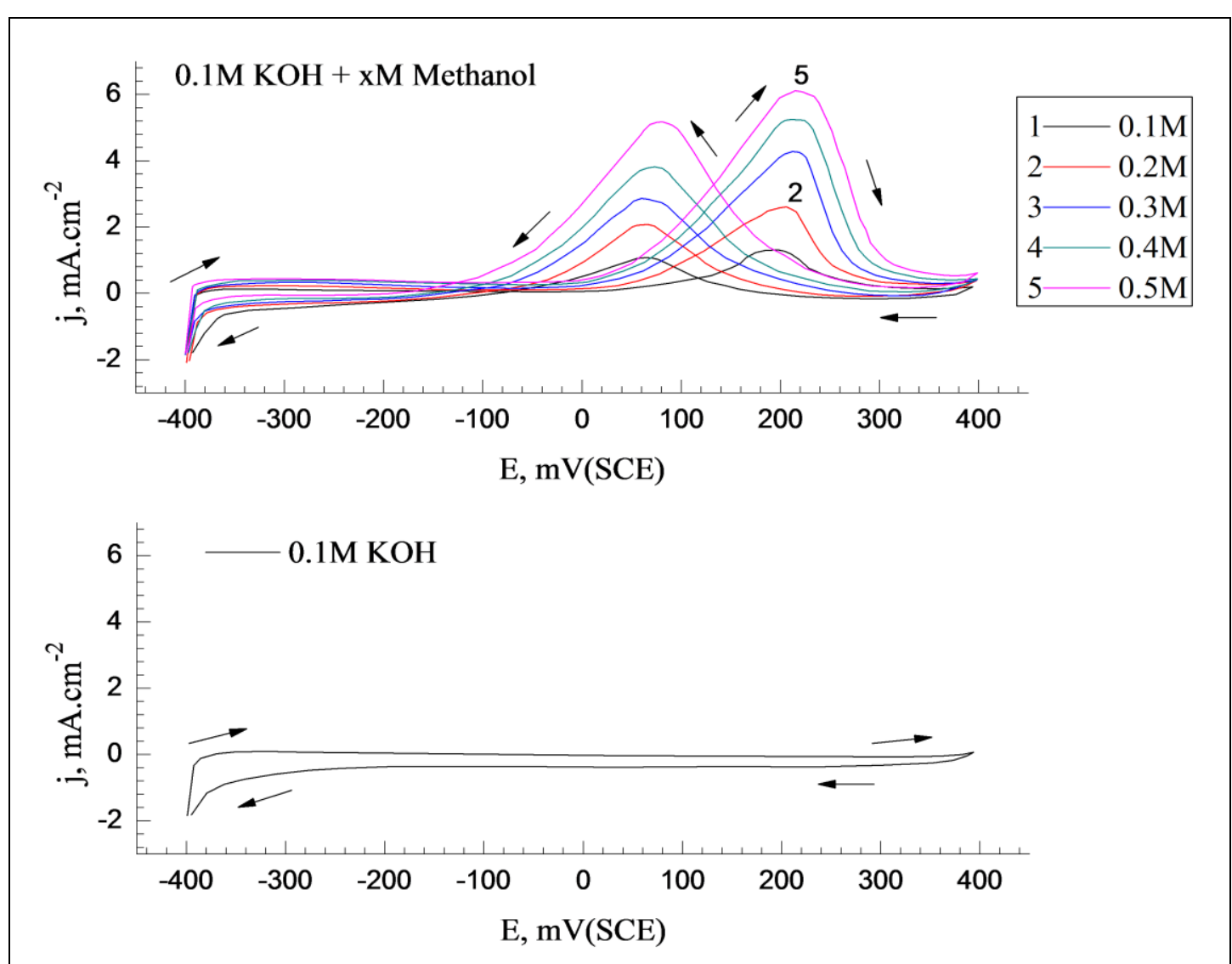

Fig. 4. Cyclic voltammograms of platinum at different concentrations of methanol, at $25^{\circ} \mathrm{C}$ (15 min. modification), at the sweep rate of $50 \mathrm{mV} \mathrm{s}^{-1}$ in $0.1 \mathrm{M} \mathrm{KOH.}$ 
Military Technical College Kobry El-Kobbah, Cairo, Egypt

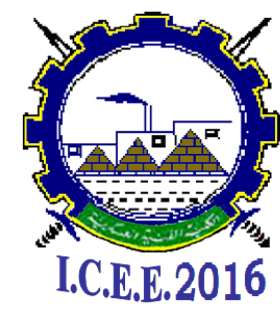

$8^{\text {th }}$ International Conferenc

on

Chemical \& Environmenta Engineering $19-21$ April 2016

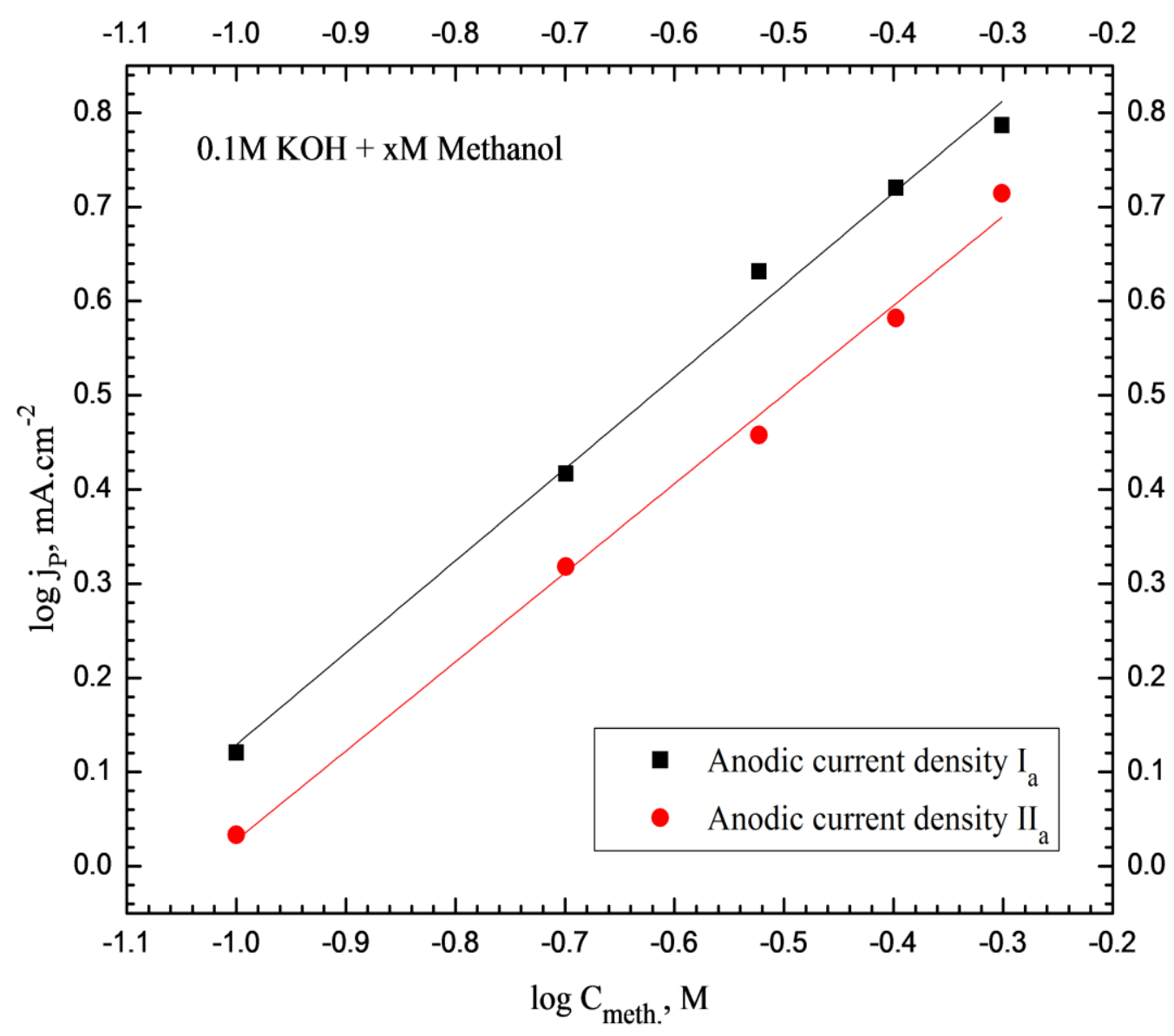

Fig. 5. Plots of the logarithm of current densities $\left(\log j_{p}\right)$ vs. the logarithm of the concentrations of methanol for each anodic and reversible anodic peak on the modified Pt electrode in $0.1 \mathrm{M} \mathrm{KOH}$ after 15 minutes of $\mathrm{Pt}$ modification, at $25^{\circ} \mathrm{C}$ 
Military Technical College Kobry El-Kobbah,

Cairo, Egypt

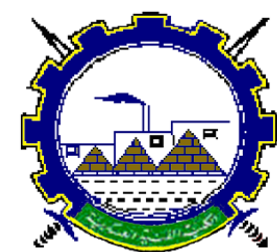

I.C.E.E.2016 $8^{\text {th }}$ International Conferenc

on

Chemical \& Environmenta Engineering 19-21 April 2016

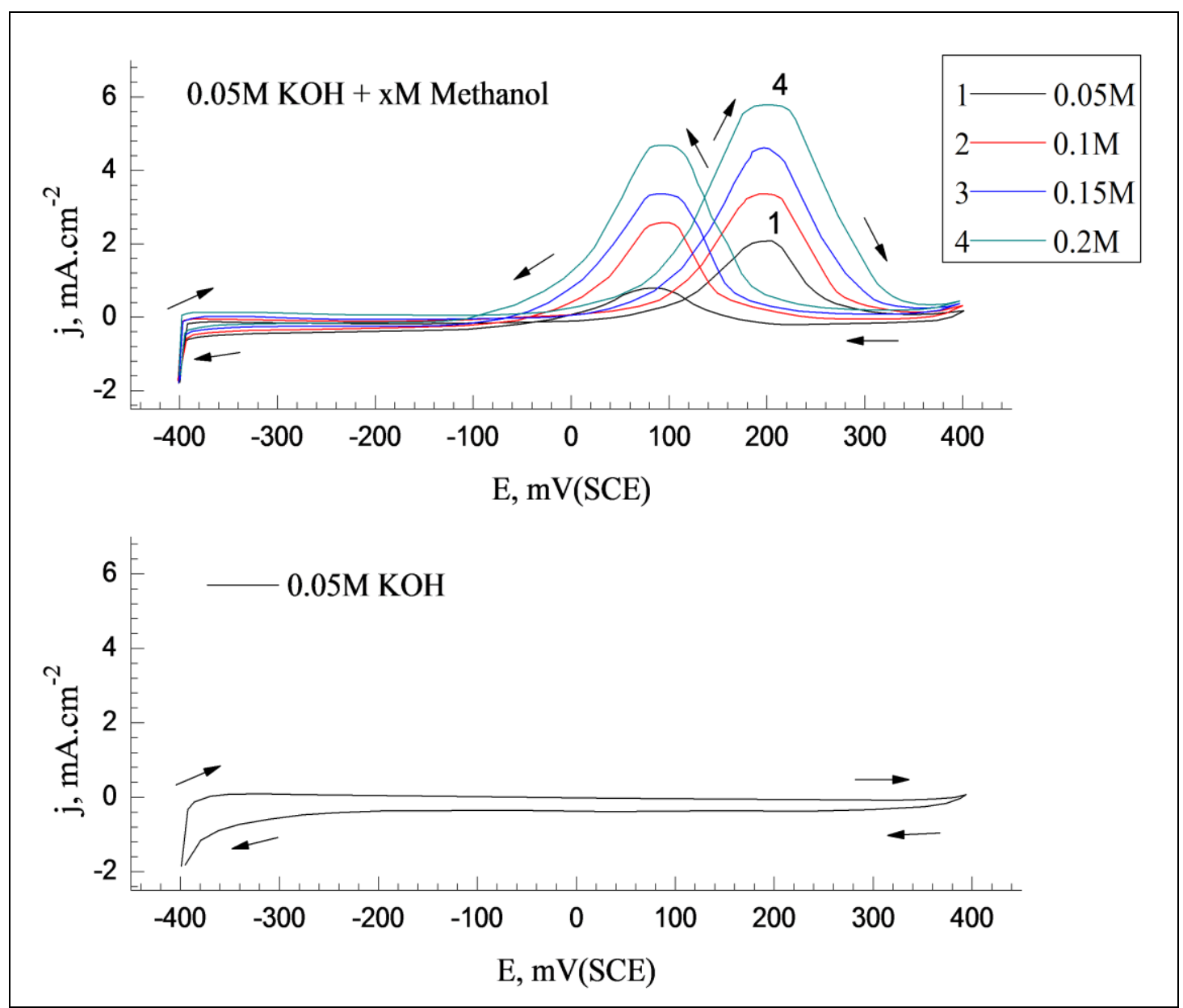

Fig. 6. Cyclic voltammograms of platinum at different concentrations of methanol, at $25^{\circ} \mathrm{C}$ (15 min. modification), at the sweep rate of $50 \mathrm{mV} \mathrm{s}^{-1}$ in $0.05 \mathrm{M} \mathrm{KOH}$. 
Military Technical College Kobry El-Kobbah, Cairo, Egypt

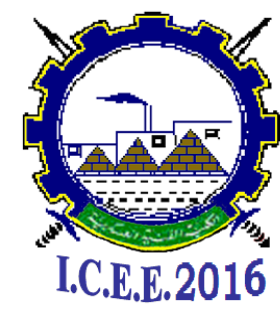

$8^{\text {th }}$ International Conferenc

on

Chemical \& Environmenta Engineering $19-21$ April 2016

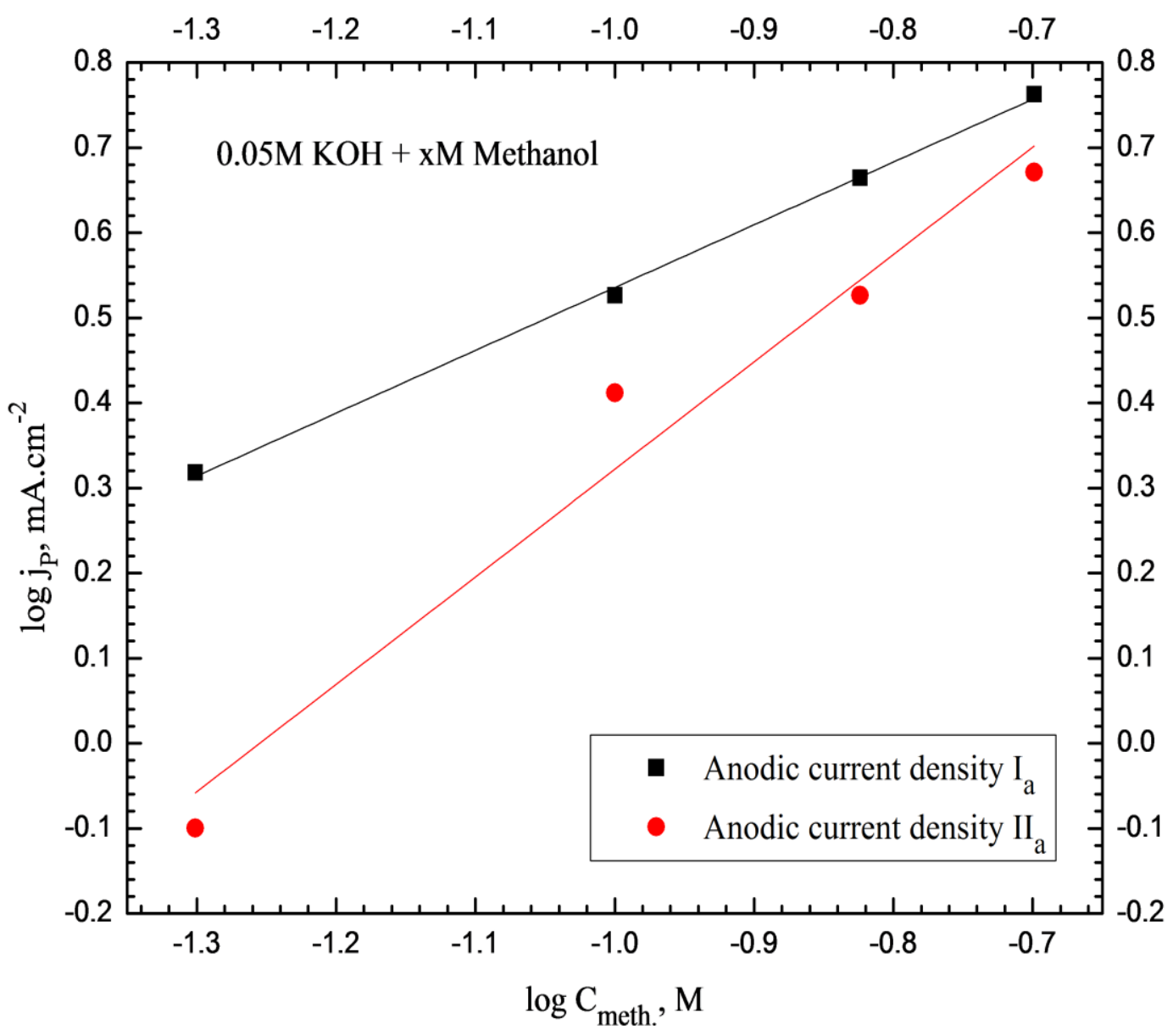

Fig. 7. Plots of the logarithm of current densities $\left(\log j_{p}\right)$ vs. the logarithm of the concentrations of methanol for each anodic and reversible anodic peak on the modified Pt electrode in $0.05 \mathrm{M} \mathrm{KOH}$ after 15 minutes of $\mathrm{Pt}$ modification, at $25^{\circ} \mathrm{C}$. 
Military Technical College Kobry El-Kobbah,

Cairo, Egypt

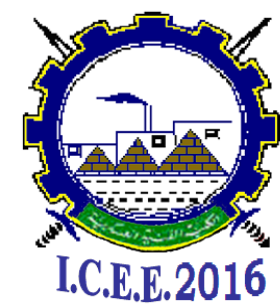

$8^{\text {th }}$ International Conferenc

on

Chemical \& Environmenta Engineering

$19-21$ April 2016

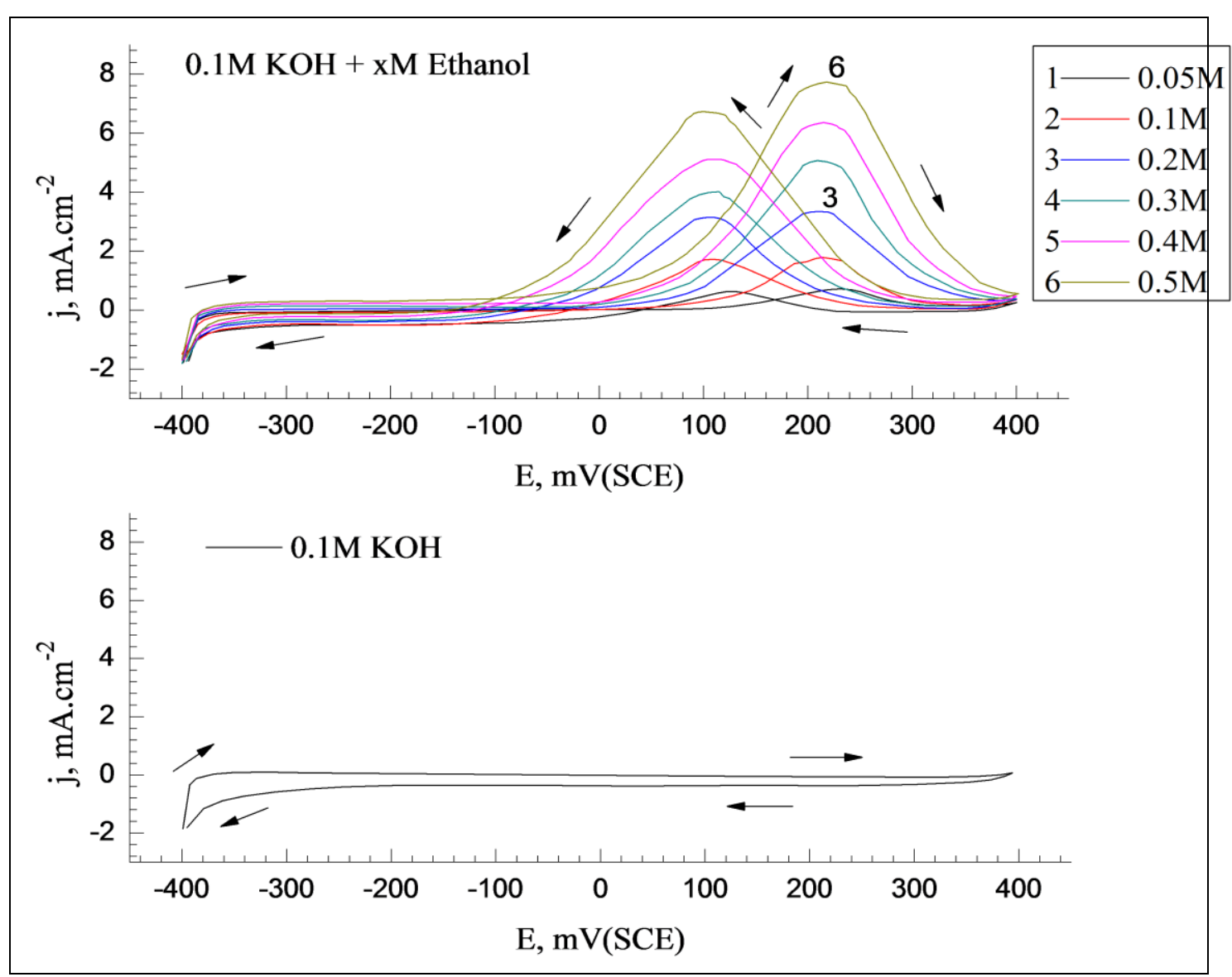

Fig. 8. Cyclic voltammograms of modified platinum at different concentrations of ethanol, at $25^{\circ} \mathrm{C}\left(15 \mathrm{~min}\right.$. modification), at the sweep rate of $50 \mathrm{mV} \mathrm{s}^{-1}$ in $0.1 \mathrm{M} \mathrm{KOH}$. 
Military Technical College Kobry El-Kobbah,

Cairo, Egypt

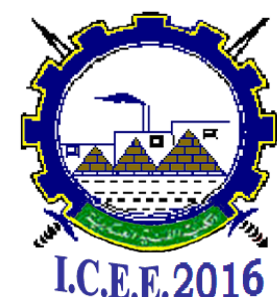

I.C.E.E.2016 $8^{\text {th }}$ International Conferenc

on

Chemical \& Environmenta Engineering

$19-21$ April 2016

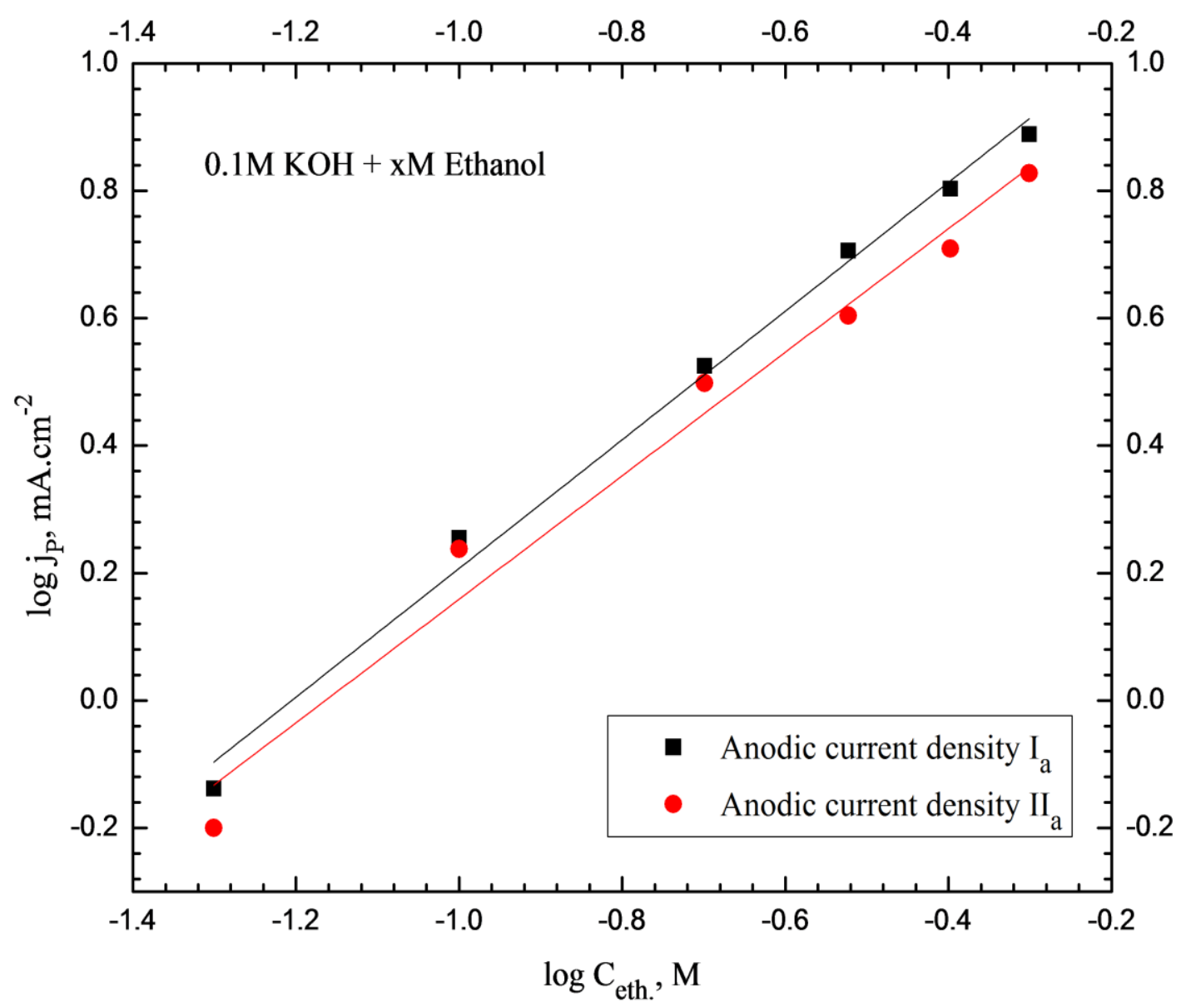

Fig. 9. Plots of the logarithm of current densities $\left(\log j_{p}\right)$ vs. the logarithm of the concentrations of ethanol for both anodic $\left(\mathrm{I}_{\mathrm{a}}\right)$ and reversible anodic $\left(\mathrm{II}_{\mathrm{a}}\right)$ peaks on the modified Pt electrode in $0.1 \mathrm{M} \mathrm{KOH}$ after 15 minutes of modification, at $25^{\circ} \mathrm{C}$. 
Military Technical College Kobry El-Kobbah, Cairo, Egypt

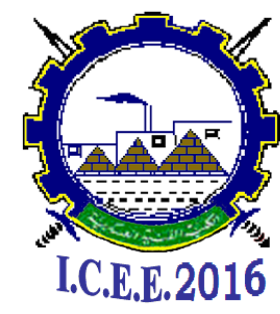

$8^{\text {th }}$ International Conferenc

on

Chemical \& Environmenta Engineering $19-21$ April 2016

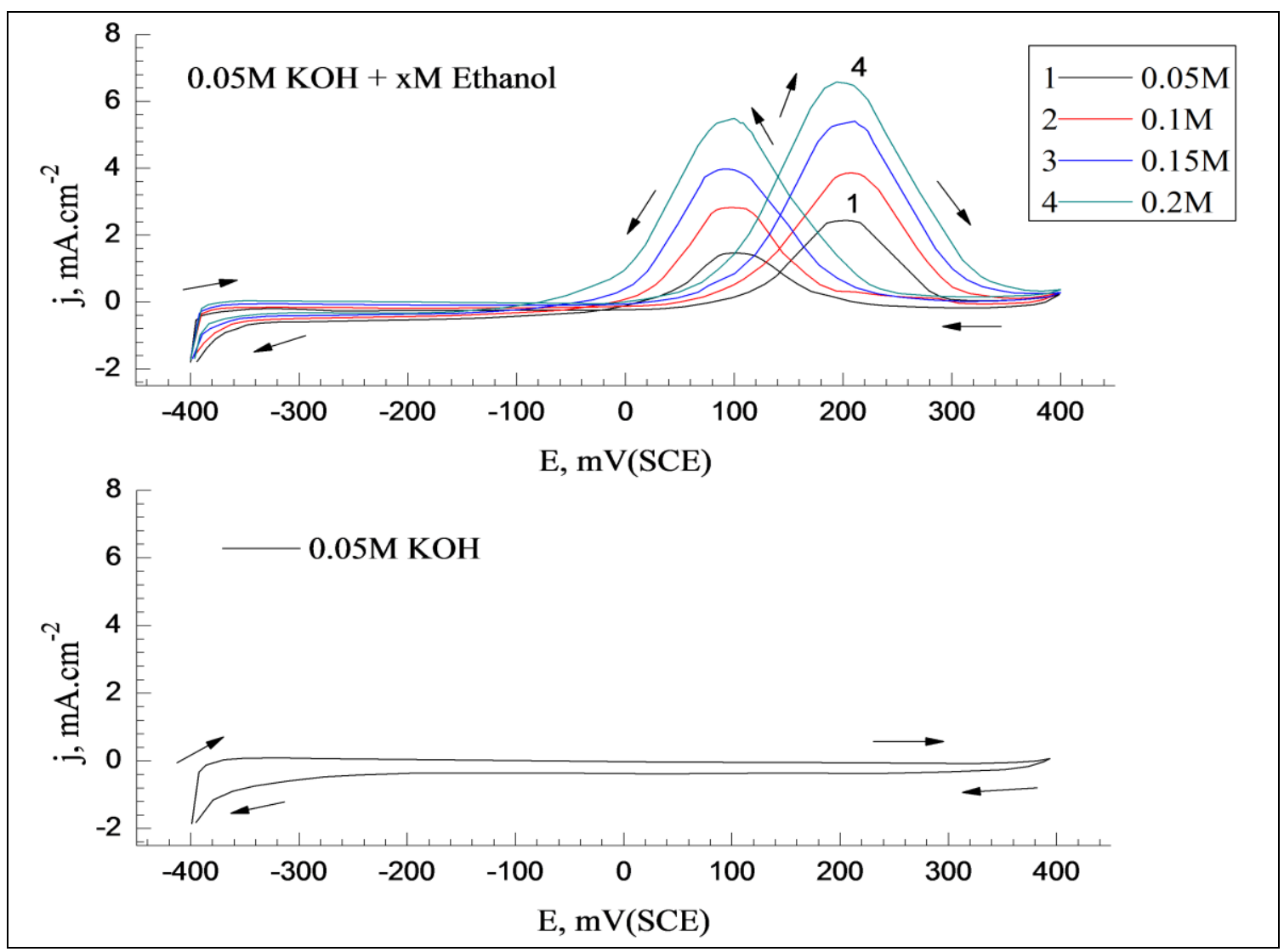

Fig. 10. Cyclic voltammograms of platinum at different concentrations of ethanol, at $25^{\circ} \mathrm{C}$ (15 min. modification), at the sweep rate of $50 \mathrm{mV} \mathrm{s}^{-1}$ in $0.05 \mathrm{M} \mathrm{KOH}$. 
Military Technical College Kobry El-Kobbah, Cairo, Egypt

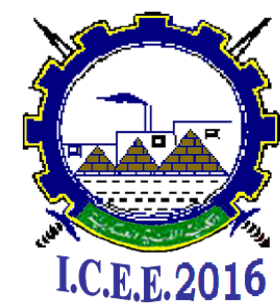

I.C.E.E.2016 $8^{\text {th }}$ International Conferenc

on

Chemical \& Environmenta Engineering $19-21$ April 2016

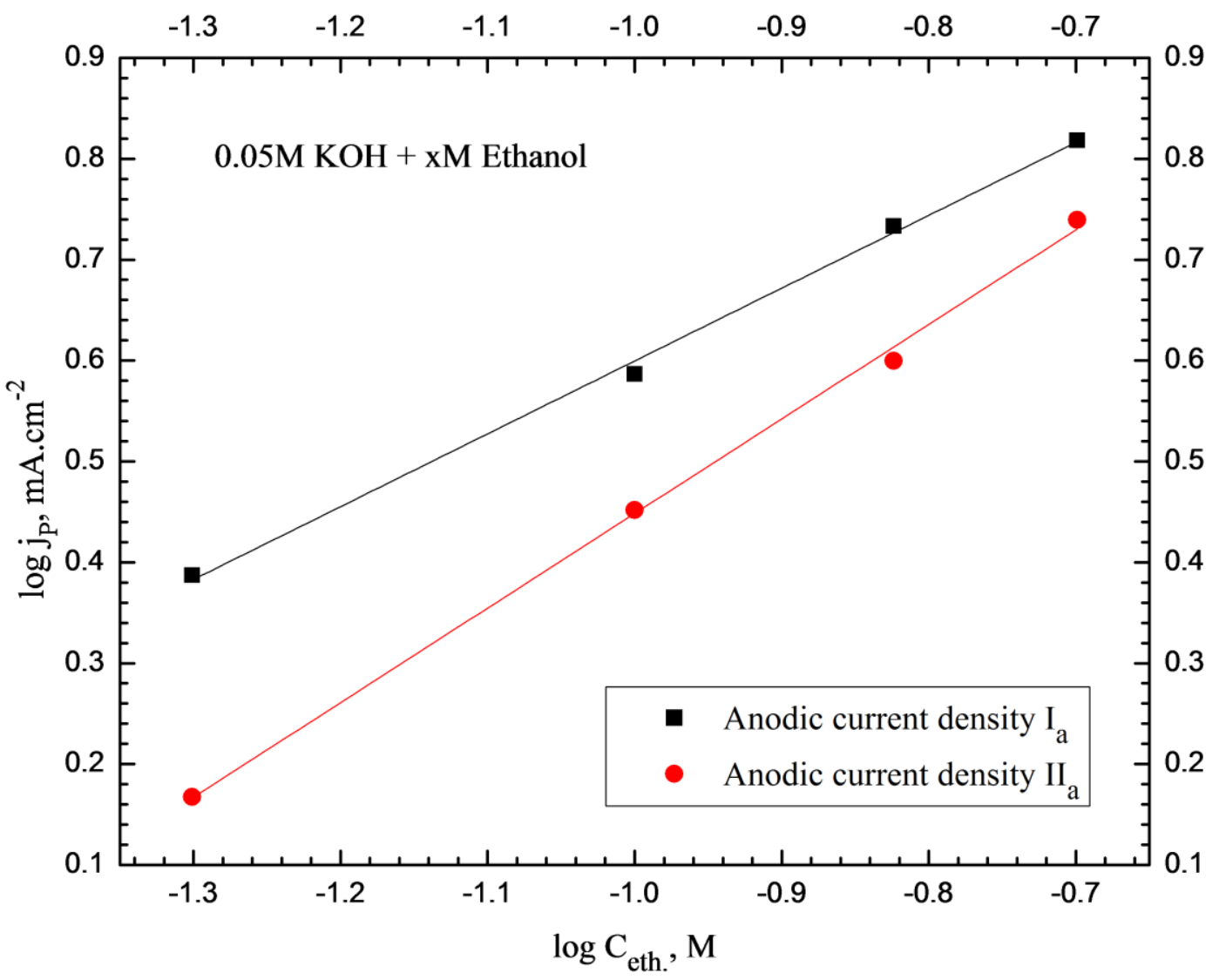

Fig. 11. Plots of the logarithm of current densities $\left(\log j_{p}\right)$ vs. the logarithm of the concentrations of ethanol for both anodic $\left(\mathrm{I}_{\mathrm{a}}\right)$ and reversible anodic $\left(\mathrm{II}_{\mathrm{a}}\right)$ peaks on the modified Pt electrode in $0.05 \mathrm{M} \mathrm{KOH}$ after 15 minutes of modification, at $25^{\circ} \mathrm{C}$. 
Military Technical College Kobry El-Kobbah, Cairo, Egypt

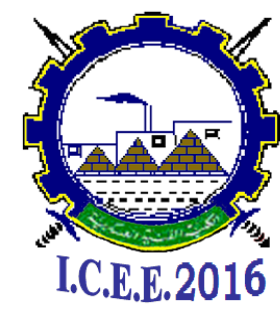

$8^{\text {th }}$ International Conferenc

on Chemical \& Environmenta Engineering $19-21$ April 2016

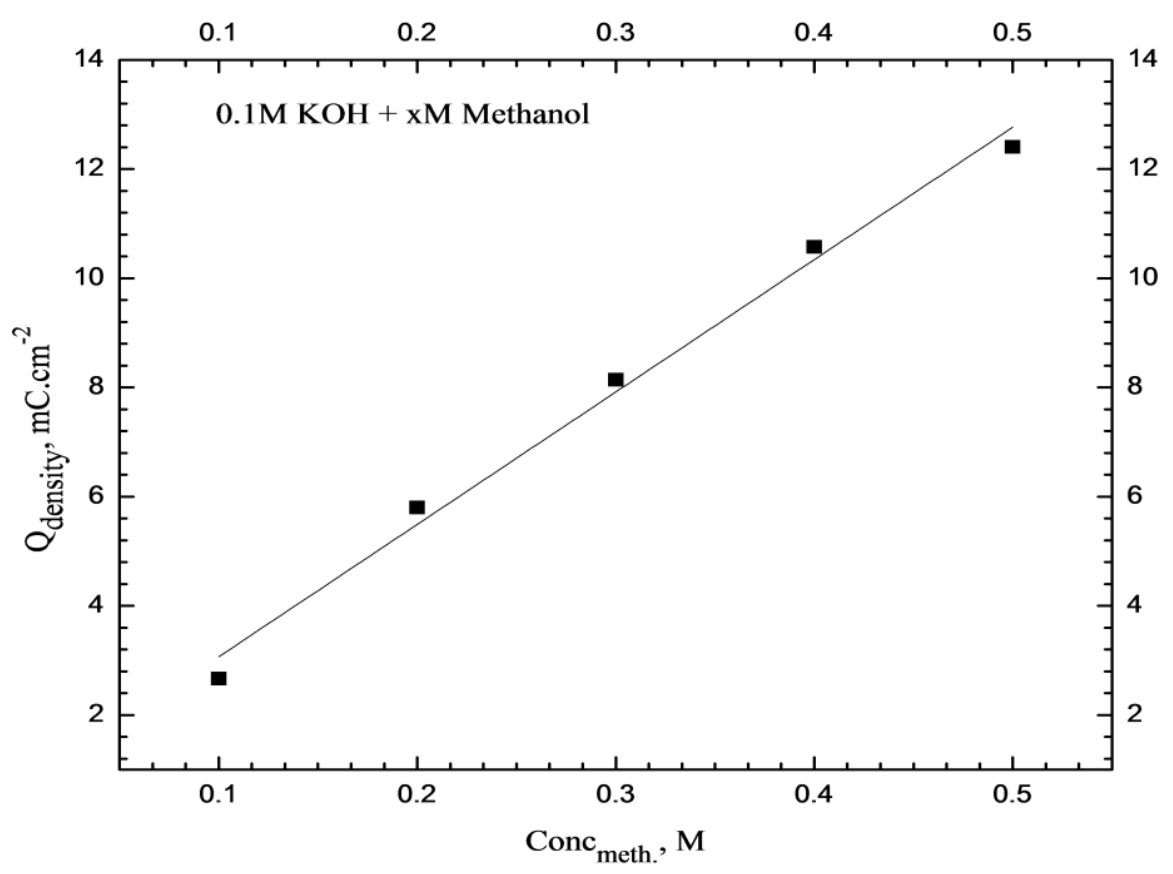

Fig. 12. Charge densities vs. methanol concentration in $0.1 \mathrm{M} \mathrm{KOH}$ for peak $\left(I_{a}\right)$, after 15 minutes of Pt modification.

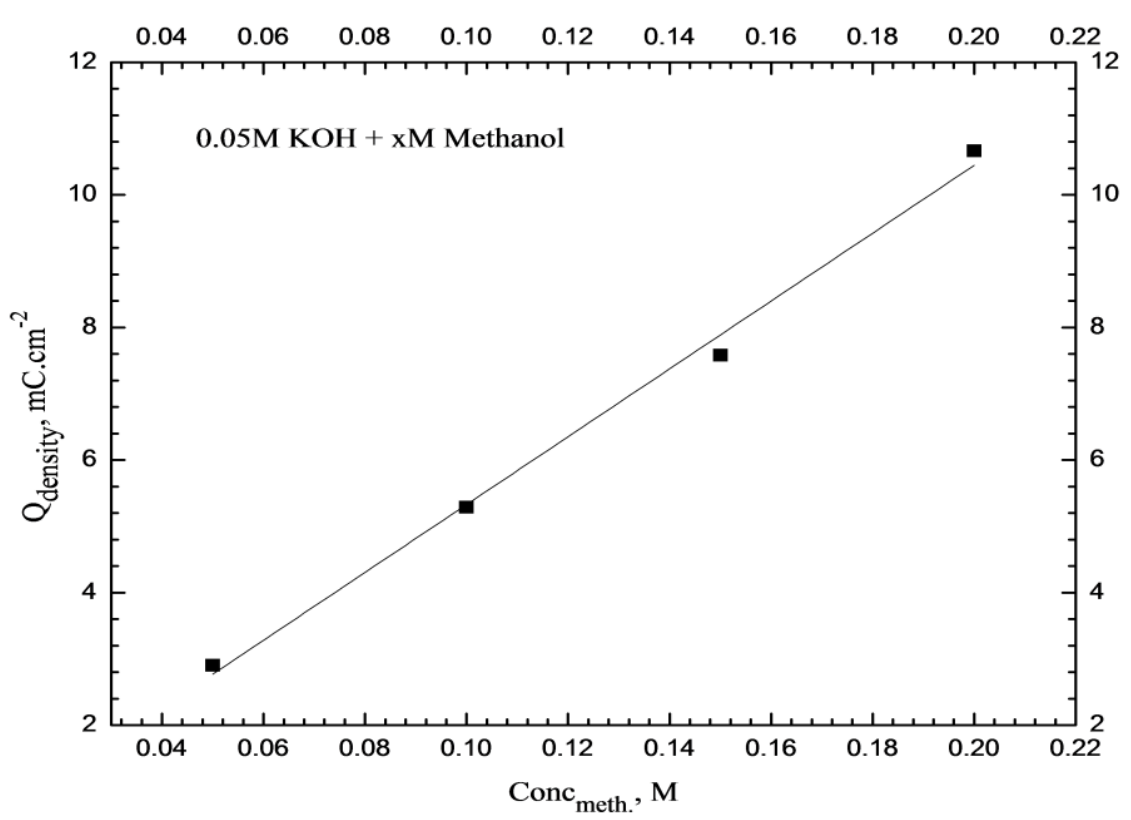

Fig. 13. Charge densities vs. methanol concentration in $0.05 \mathrm{M} \mathrm{KOH}$ for peak $\left(I_{a}\right)$, after 15 minutes of Pt modification. 
Military Technical College Kobry El-Kobbah, Cairo, Egypt

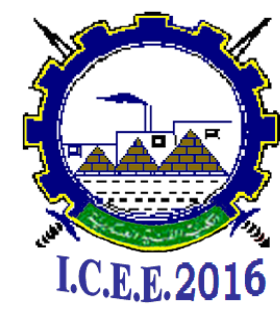

$8^{\text {th }}$ International Conferenc

on Chemical \& Environmenta Engineering $19-21$ April 2016

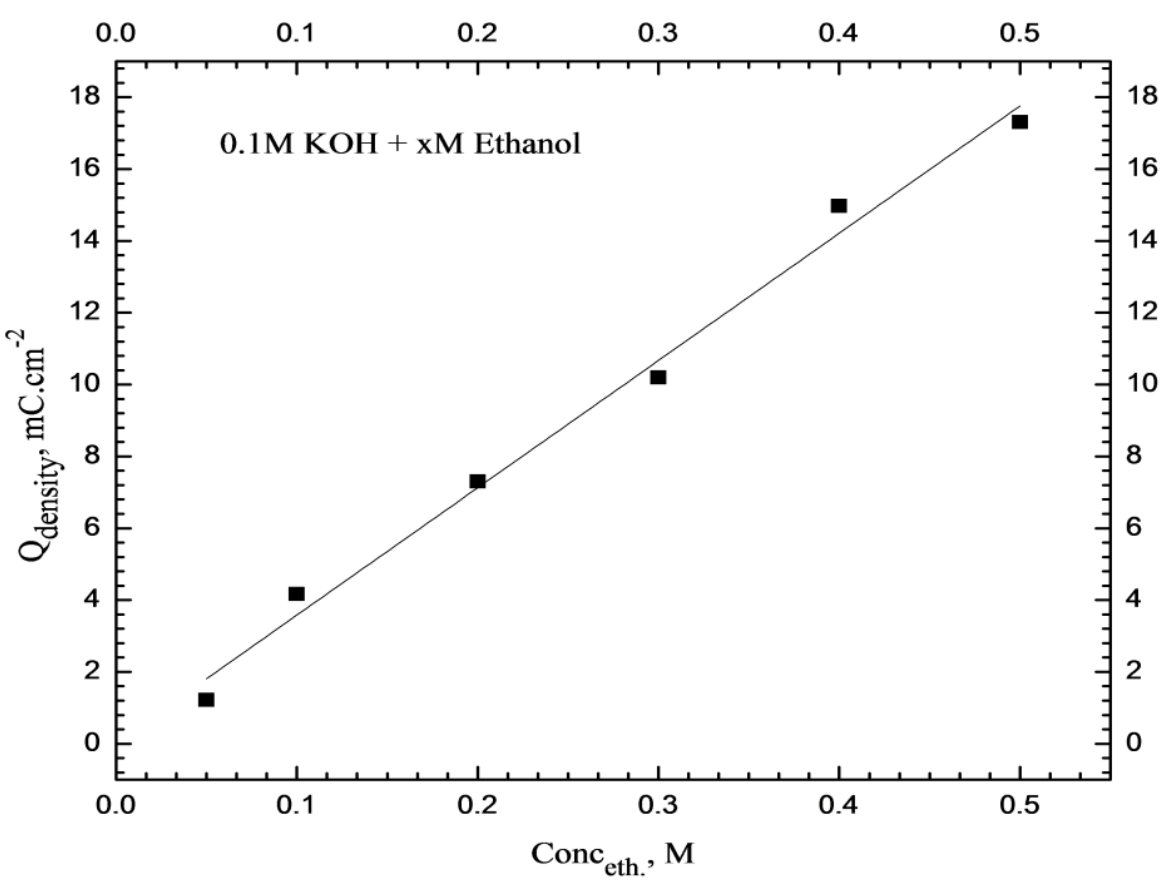

Fig. 14. Charge densities vs. ethanol concentration in $0.1 \mathrm{M} \mathrm{KOH}$ for peak $\left(\mathrm{I}_{\mathrm{a}}\right)$, after 15 minutes of Pt modification.

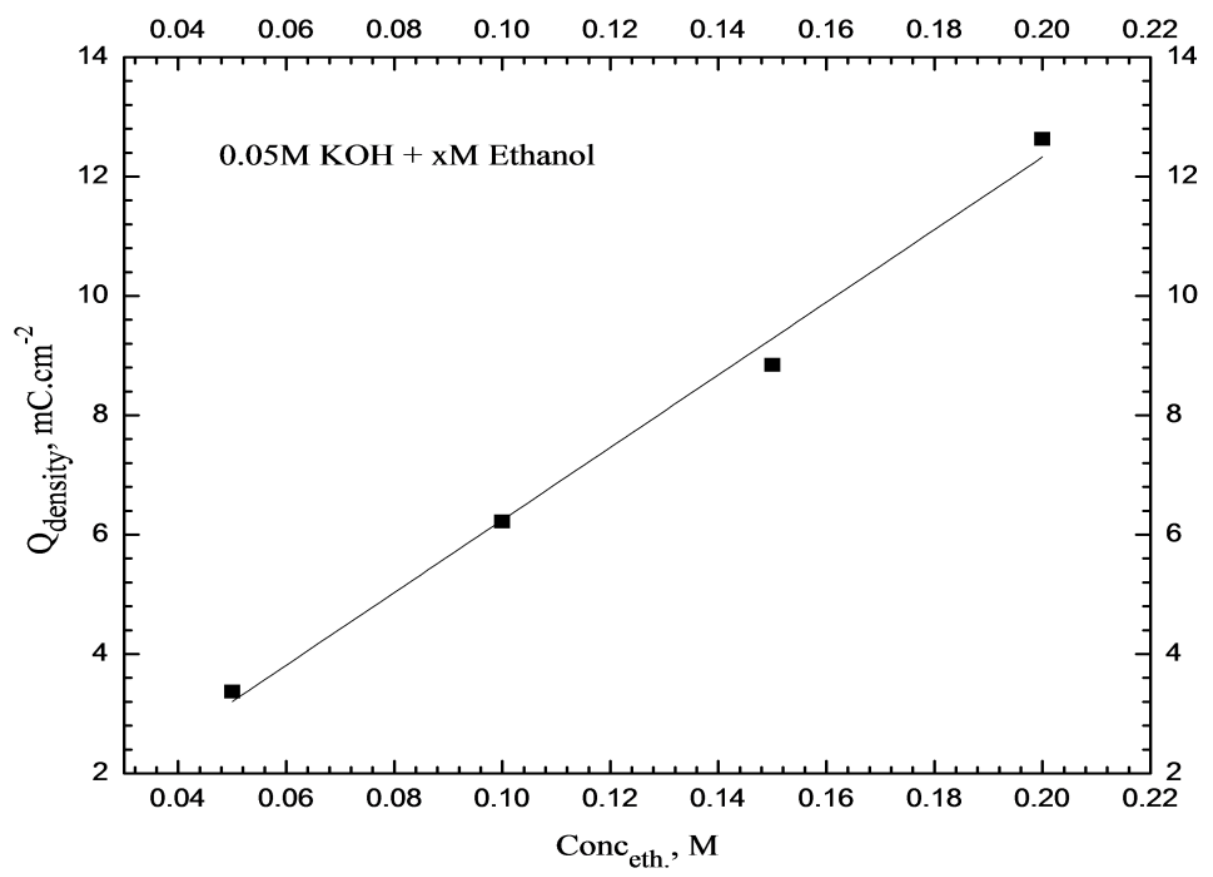

Fig. 15. Charge densities vs. ethanol concentration in $0.05 \mathrm{M} \mathrm{KOH}$ for peak $\left(I_{a}\right)$, after 15 minutes of Pt modification. 